\title{
State, Security and Insurance
}

An analysis of social security policy in some Western industrial societies

\author{
by Walter Ackermann *
}

The following essay contains the most important findings of a comprehensive research project undertaken by the Institute of Insurance Economics on behalf of the Association Internationale pour l'Etude de l'Economie de l'Assurance in the years $1976 / 77$. The Final Report on this project has been published in German in the "Etudes et Dossiers" Nos. 19 and 20 of the Association de Genève.

This summary report has the following contents :

1. The Problem Complex

1.1. Present Situation

1.2. The Brief

1.3. Structure of the Study

1.4. Methodology

2. Social Security in Industrial Nations : A Comparison of Social Security Benefits and Costs

2.1. Objectives and Background of the Comparison

2.2. Service Level of Social Security Systems as seen by Individual Working Households

2.3. Financing of Social Spending as seen by Working Households

2.4. Social Security in the Industrial Society : Reality or Illusion?

3. Basic Trends

3.1. General

3.2. Establishment and Aims of the Empirical Survey

3.3. Basic Tendencies in Social Security Policy : A Scenario

4. Aspects of Social Security : Consequences for Private Insurance

5. Social Risk Policy in the Family and Household

* Economic Research Associate, Institute of Insurance Economics of the St. Gall Graduate School of Economics, Business and Public Administration. 


\section{The problem complex}

\subsection{The present situation}

This study examines possible development tendencies of collective and private security systems at the level of individual and family in some Western European affluent societies. The core of the study is an analysis of the comprehensive security measures known by the name of national insurance or - more precisely - social security policy.

Starting from the current stage of development of these collective security systems in certain advanced industrial states, the study proceeds to discuss possible aspects of social security policy, and concludes with a debate on some direct effects of the future development of the social sector on private security activities and thus on private insurance itself.

The term "social security" has become enormously widespread since its inclusion in the Declaration of Human Rights (1948, Art. 22). Despite this fact, or perhaps because of it, we still lack any uniform definition, and we should therefore like to define the tasks of a modern concept of social security policy for the purpose of our discussion as follows :

A social security policy guarantees the economic existence of the whole population in all life situations and safeguards attained social status in the economically and socially decisive situations of life such as old age, decease of the income earner, sickness or accident, etc.

The following debates concern therefore all state and non-state measures whose chief aim is to attain these dual objectives: to guarantee economic existence and to safeguard attained social status.

In the forefront of considerations are of course the social insurance organisations (old-age and survivors insurance, disability insurance, workmen's compensation, unemployment benefit, etc.) as well as a wealth of nationally varying social assistance benefits and services (both cash and goods) such as advisory services, rent allowances, family assistance, educational allowances and so on. In addition, statutory and non-statutory schemes with similar objectives (such as company-operated pension funds or charity supplemental systems, private insurances) must be considered where possible.

If we analyse the policies of social security over the past years in some highly industrialised countries with comparable social and economic environments, we find a whole series of coinciding problems and facts. The following specific trends are of significance for our examination:

A) Rapid, mainly pragmatic growth in social security systems

Although the origins of the oldest social security systems go back to the 19th century, the real establishment and expansion of the Western welfare states did not occur until ten to twenty years ago, in the wake of rapid economic growth. In nearly all advanced countries, the social sector shows above-average growth in this time period, both by comparison with the national product and as against other state expenditure items. Today, the social sector budgets of modern welfare states absorb some $25-35 \%$ of the Gross National Product (GNP). 
B) Absence of common consensus on aims and objectives of social policy

At the same time, this rapid, and for many people over-hasty, expansion of collective security systems occurred without any clear objectives, leading to largely uncoordinated and mainly monetary socio-political activities. In the democracy of competition, the compulsion to safeguard power usually renders coordinated expansion impossible; social policy therefore, as perhaps the most important instrument in maintaining power, is frequently subordinated to largely short-term objectives.

C) Uncertainty regarding future focal points of development

As long as the basic aims of social security policy (to guarantee a minimum subsistence and to safeguard social status) were only partly achieved, the simple formula "increased (monetary) services must perforce improve the quality of security" held good. Today, the original aims and objectives of social security policy in leading social states have been largely achieved (cf. remarks in Chapter 2). As the demand for an abandonment of additional expansion programmes would seem unrealistic given the predominant political and social structures, the question of the future development of social security takes on quite a different value than it had five or ten years ago.

D) Diminishing fringe benefits of additional social investment

Developments in social security policy over the past years may be characterised by the terms "dynamic stagnation". More and more financial and political resources are flowing into the comprehensive systems of social security on the one hand - hence the use of the epithet "dynamic" - while one gains the almost universal impression that the feeling of security in the recipients of social services has not grown parallel to the social budget in the past years. Thus we find that most countries are undertaking a wide variety of activities to raise the impact of their socio-political instruments. This tendency should become even more marked in the coming years. An increasing shortage of socio-political means - the result of a changed economic climate, the unfavourable development in the ratio of social service recipients and contributors as well as of widespread public poverty - heightens the necessity of enhancing the efficacity of existing social programmes and the fringe benefit of additional investment in the social sector. To achieve this aim, our society cannot avoid having to appraise the complex value idea of "security" from the viewpoint of individual and family much more precisely.

E) Increasing need of security among population

Modern research into public needs provides evidence of an increasing need for security among the population of today's industrial states of the West. The ongoing debate on current problem situations such as pollution, population explosion, growth restriction, international terrorism, etc. can actually be seen as a sign of growing external threats and jeopardising of external security which in many instances leads to a loss of internal security.

F) Jeopardising of socio-economic stability

The tendencies sketched above justify talk of a crisis in social or welfare states, a crisis which in the long term could lead to jeopardising of socio-economic stability and thus to the destruction of the social and economic order. It is important to note 
here that both inadequate development and inappropriate expansion in the social sector could cause this effect. The conditions under which a social policy could be anti-social or anti-economic have as yet hardly been researched.

\subsection{Brief of the Association Internationale pour l'Etude de l'Economie de l'Assurance}

With reference to this problem analysis, the Association Internationale pour l'Etude de l'Economie de l'Assurance, after detailed preliminary discussions, has entrusted the following brief to the Institute of Insurance Economics at the University of St. Gallen :

To define the structure of collective and private security measures for individuals and families in certain economically advanced industrial states of Western Europe, and to show the major determining factors of future development and possible qualitative and quantitative tendencies.

Geographically, this study covers the following countries :

- Federal Republic of Germany;

- Great Britain ;

- France;

- Sweden;

- Switzerland.

All these are economically advanced industrial states with comparable economic and social frameworks, although their socio-political objectives may be widely different.

\subsection{Structure of the study}

The content of the study bears on four focal points :

\section{A) Current state of collective security measures}

The following comparison (in Chapter 2) attempts in particular to define the national systems of social security on the basis of concrete examples from the viewpoints of individual working households, and to appraise them with the aid of a uniform screening process.

B) Trends and limits of social security policy

As set forth in section 1.1, social security policy is at a crossroads, and any attempt to sketch potential futures of the modern social state will stumble upon considerable difficulties. With the aid of interviews, questionnaires and theoretical analyses, we have been able within the scope of this research project to clarify which determining factors and development tendencies should generally affect the future social security policies of the affluent states of the West. The most important results of this investigation are contained in Chapter 3.

C) Position of private insurance

There can be no doubt that the rapid development of social states has had a direct influence on the expansion of private insurance. In a separate section therefore (cf. 
Chapter 4), we shall look at some of the consequences of future developments in social security on private insurance sectors.

D) Social risk policy

There is general consensus among researchers that concepts will be more important than forecasts for successful solutions to future problems. In a final section (Chapter 5) we shall therefore discuss under the heading "Social Risk Policy" some considerations on which both collective and private insurance measures and security instruments could in future be based.

\subsection{Methodology}

Our methodical procedure in the present study was decisively influenced both by the extraordinary broad subject of investigation as well as by the available timescale. The complexity of the topic thwarted all attempts to log potential development trends of social security systems with the aid of a simulation model. Extrapolations and trend assessments are moreover little suited, in times of tangible structural changes and trend inroads, to produce any meaningful results. This is why the following study operates on the "scenario writing" approach, by which we mean a partly verbal, partly mathematical description of a future condition combined with an attempt, with reference to qualitative and quantitative statements, to draw as complete a picture as possible of the subject examined. To acquire the necessary information, we carried out interviews and worked partly with questionnaires in the various countries in addition to processing the most important subject literature. Detailed guidance on this is given in the introduction to Chapter 3.

\section{Social securlty In Industrlal nations : a comparison of soclal security benefits and costs}

\section{2.l. Objectives and background of the comparison}

A multitude of comparative studies are available in the sphere of social security. The available material is as a rule based on two points of approach. The scope and effects of input and output streams are frequently in the forefront of discussions, with discussion points formed by overall economic implications which are scarcely operable. Other investigations use synoptic tables to give information on the basic organisational and legislative structures of social security systems, such as the minimum or maximum social service arrangements, the most important financing principles and so on. Both approaches are of undoubted usefulness. Both however suffer from the disadvantage that they do not permit any conclusions as to the effects of social security on those who are in the final analysis directly affected : the recipients of social services.

We shall now make on attempt to log, as comprehensively and as near to practice as possible, the financial services and thus the effects of social security systems with the aid of concrete examples from the viewpoint of individual working households. In addition to social service requirements, we shall look at the financial burden on individual income resulting from social security. 
In other words: The present inquiry will attempt to establish, with the aid of actual cases and circumstances, the level of the benefits provided by the various insurance carriers, which an insured person (or the members of his family) receives in the event of old age, death, invalidity, sickness or unemployment. The examples cited were selected in such a way, regarding the family and financial conditions of the insured, that they apply to the largest possible portion of the population in each country investigated. The study compares, in all social insurance areas except old age provisions and benefits, the position of a married couple approaching middle age with two or three children and the husband as the only breadwinner (employed by an industrial or service organization). It was assumed that the couple did not own any substantial assets and that the contributions to social insurance schemes were paid regularly.

For the purpose of determining the dependence of social benefits on the size of the (earlier) earnings of the insured, the study always compared three different income categories for each country. The calculations of these income classes rest on the income conditions customary in the individual nations. As these vary from country to country, it is not sufficient to restrict the comparison to three specified income levels and to convert them into the national currency by employing the corresponding exchange rate. For one, exchange rates do not reflect the actual purchasing power relations. Secondly, specifying uniform income levels does not cover the income structure representative of each country. For example, an annual income from employment of Sfr. 20000 (\$8 097) lies only slightly below the national average in Switzerland whereas it far exceeds the average earnings in Great Britain once it is converted into pounds sterling.

Against this background, the three income categories were determined differently for each country. The starting point is formed by the average earnings of an employee in an industrial or service enterprise. This solution is supported also by the fact that the maximum benefits of the individual social insurance systems are often very closely related to the average national income figures. These additionally calculated higher income levels are listed in percentages of the underlying average earnings (base year: 1975).

\section{- Income Category 1}

This level equals the average annual earnings, before any deductions, of a wage or salary earner in an industrial or service company $(=100 \%)$. In Switzerland it comes to annual gross earnings of Sfr. 24200 (\$9798).

\section{- Income Category 2}

This income level is equal to $150 \%$ of category 1 . As a rule, it is characteristic of the income earned by the household of a white-collar employee, which is higher than the general average. In Switzerland it is equivalent to an annual income from wage or salary compensation of Sfr. 36300 (\$14 696).

\section{- Income Category 3}

This income level is equivalent to $250 \%$ of category 1 . It can be regarded as approximating the income situation of the upper middle class. In Switzerland, this amounts to annual gross earnings of Sfr. 60500 (\$24 494). 
As Figure 1 shows, this approach aims at recording a representative majority of income earners and/or working households in all the countries in question. It may be surprising to note at first glance that the position of the earners of the lowest incomes is somewhat neglected. We should remember here that "average income" as a yardstick does justice even to the position of low-income brackets. This approach is further justified by the objectives of modern social security policies : unlike the beginnings of the national insurance epoch, today's social security policies are largely orientated to the needs of the "average" citizen, the "normal" working man and his family. In other words: modern national insurance schemes primarily aim at a need-orientated distribution of income earnings over all life phases; they therefore play a protective role for the majority of the population. This fact makes it impossible to consider the situation of low-income brackets individually or particularly in a comparison between various national systems of social security.

Fig. 1 - The three income variants in the light of income distribution

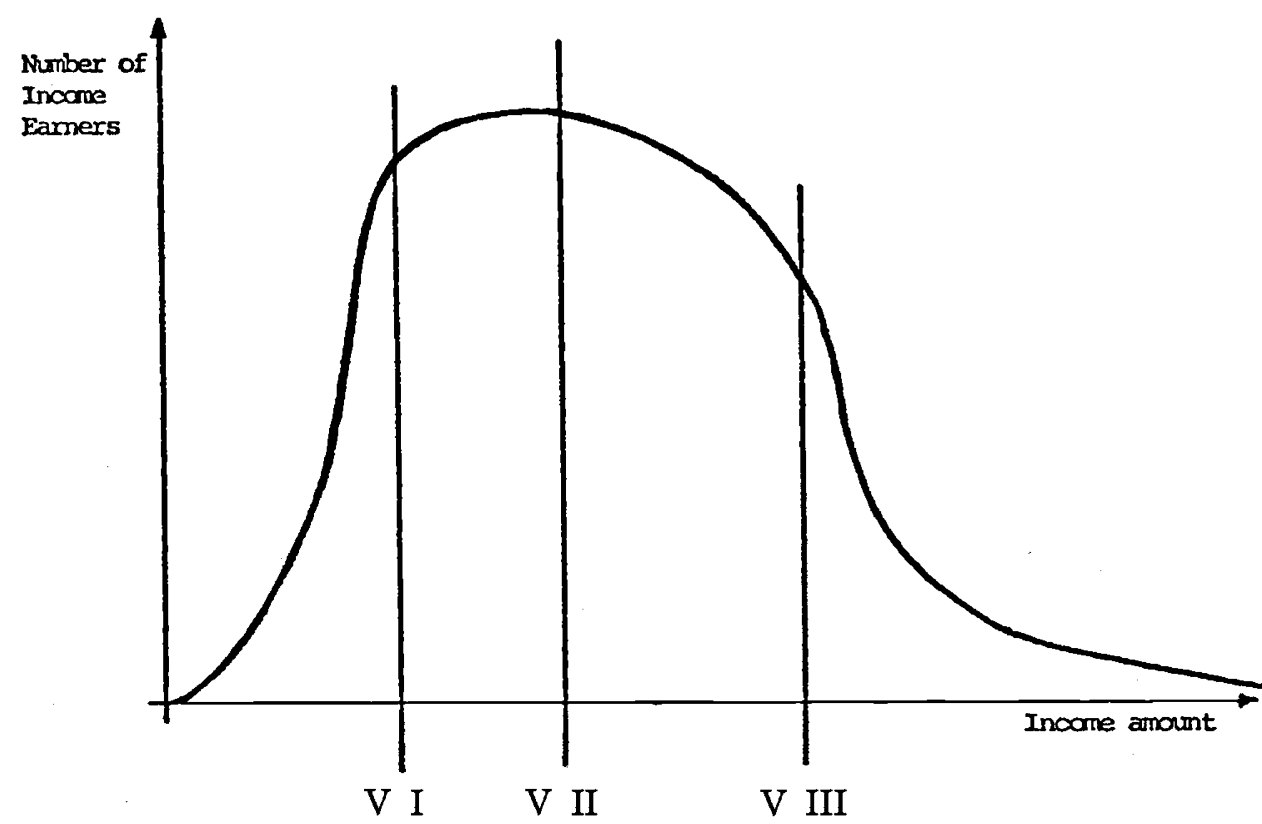

The income distribution characteristic is of course not identical for all countries. The initial value V I (= average income) however guarantees that the three income variants encompass a representative population majority in all countries.

If these percentages are applied to the average earnings of industrial workers in the countries surveyed, one arrives at the annual earnings reproduced in Table 1. Converted into U.S. dollars, income category 1 represents gross earnings that range from $\$ 4487$ in Great Britain to $\$ 10162$ in Canada. 
Table 1 - Annual earnings of employee households

in western industrial nations : 1975

\begin{tabular}{llccc}
\hline Country & Currency $a$ & $\begin{array}{l}\text { Income } \\
\text { category } \\
(=100 \%)\end{array}$ & $\begin{array}{l}\text { Income } \\
\text { category } 2 \\
(=150 \%)\end{array}$ & $\begin{array}{c}\text { Income } \\
\text { category 3 } \\
(=250 \%)\end{array}$ \\
\hline $\begin{array}{llcc}\text { Federal Republic } \\
\text { of Germany }\end{array}$ & $\begin{array}{l}\text { DM } \\
(\$)\end{array}$ & 20700 & 31050 & 51750 \\
France & Ffr. & $(8322)$ & $(12483)$ & $(20805)$ \\
& $(\$)$ & 34872 & 25308 & 87180 \\
Great Britain & $\mathbf{( 7 6 8 2 )}$ & $(10611)$ & $(17685)$ \\
Sweden & $(\$)$ & 2620 & 3930 & 6550 \\
& Skr. & $(4487)$ & $(6730)$ & $(11217)$ \\
Switzerland & $(\$)$ & 34100 & 51150 & 85250 \\
& Sfr. & $(7842)$ & $(11762)$ & $(19604)$ \\
Belgium & $(\$)$ & 24200 & 36300 & 60500 \\
& Bfr. & $(9798)$ & $(14696)$ & $(24494)$ \\
Canada & $(\$)$ & 271000 & 406500 & 677500 \\
& Can. $\$$ & $(7077)$ & $(10615)$ & $(17692)$ \\
USA & $(\$)$ & 9960 & 14940 & 24900 \\
& $\$$ & $(10162)$ & $(15243)$ & $(25404)$ \\
\hline
\end{tabular}

a Converted into dollars at the average exchange rates during the third quarter of 1976. Source : International Labour Office (ILO).

Income variations from country to country also render impossible a direct comparison of the social benefits depending on this income. In order to take this incomparability into account, the social benefits are not expressed in absolute amounts but in percentages of former wage or salary earnings. Due to the fact that the extent of the taxes and social insurance contributions levied on earnings and social benefits varies among the different countries, two comparative figures were calculated.

- As a first step the gross social insurance income (social insurance benefits before deduction of taxes and contributions) is compared with the gross earnings from employment (earnings according to Table 1 plus family allowances).

- As a second step, disposable net social insurance income (social insurance benefits after deduction of taxes and contributions) is compared with disposable net earnings from employment (gross earnings after deducting taxes and contributions).

Comparisons of the net amounts of social insurance benefits produce higher percentages, as a rule, than comparisons of gross amounts. This is explained by the fact that old age and retirement benefits are taxed at lower rates for socio-political 
considerations than former earnings, which has the ultimate effect of indirectly raising the monetary value of social insurance benefits.

With the aid of the factors just outlined, it becomes feasible to evaluate the current status and degree of social insurance schemes and compare them with foreign models. It should be noted, however, that the results require careful interpretation. For one, it is impossible with the employed method of calculation to cover all particular features of the various national social insurance schemes. To illustrate this, almost all countries provide today for public assistance in the form of income supplements or other supplementary benefits in situations of special need. Nevertheless an attempt was made to include these benefits in the study and show their extent, even though this did not prove possible in all cases due to the diversity of rulings and arrangements. Even the computation of the social insurance benefits met with difficulty on occasions. The often extremely complicated retirement benefit formulas and income tax legislation made it necessary repeatedly to obtain additional data in order to complement the initial information. Furthermore, large-scale individual or occupational social benefit schemes designed to supplement the benefits of government-operated social security programs are customary in some countries. Governments frequently do not keep statistics on such supplementary benefits, or it is impossible for other reasons to collect the related data. Reference has been made to this fact whenever such data were unobtainable.

It must be stated however that it will never be possible to establish an effective security programme for individuals and families with the aid of financial measures alone. Thus charity organisations in many countries today offer direct services (care of disabled, meals-on-wheels, etc.) which do not appear in any statistics. As a further example, an old-age pensioner in a small village with near, familiar surroundings and relationships will appreciate social services offered for the aged quite differently from senior citizens living in the more complex, less familiar atmosphere of a major city and not only in terms of purchasing power. The pension level will again be differently assessed by married pensioners with intact family relations.

Security is too complex a value idea, and there are too many varying needs behind the demand for security reasons and services, for a comprehensive security programme to be established with the aid of financial measures alone.

In spite of these doubts, we are convinced that the recording of the financial service requirements of individual working households will give a better insight into, and a more productive comparison of social security systems than the existing generalized surveys which are usually restricted to stating minimum and maximum service objectives of national social security systems.

\subsection{Service level of social security systems as seen by individual working households}

Social case No. 1 includes a comparison of old-age pensions of married couples in various countries. The gross comparison juxtaposes the last earned income (before deduction of taxes and social charges) and the gross pension (before deduction of taxes and social charges). The net comparison shows the available pension (after taxes and charges) in relation to the last available earned income. 
Table 2 - Retirement income ${ }^{a}$ of a married couple (as at January 1976)

\begin{tabular}{|c|c|c|c|c|c|c|}
\hline \multirow{3}{*}{ Country } & \multicolumn{3}{|c|}{ Gross Income Comparison } & \multicolumn{3}{|c|}{ Net Income Comparison } \\
\hline & \multicolumn{3}{|c|}{$\begin{array}{l}\text { Retirement income in } \% \text { of final } \\
\text { earnings before deduction of taxes } \\
\text { and social security contributions } b\end{array}$} & \multicolumn{3}{|c|}{$\begin{array}{l}\text { Retirement income in } \% \text { of final } \\
\text { earnings after deduction of taxes } \\
\text { and social security contributions } c\end{array}$} \\
\hline & $\begin{array}{l}\text { Income } \\
\text { category } 1 \\
(=100 \%)\end{array}$ & $\begin{array}{l}\text { Income } \\
\text { category } 2 \\
(=150 \%)\end{array}$ & $\begin{array}{l}\text { Income } \\
\text { category } 3 \\
(=250 \%)\end{array}$ & $\begin{array}{l}\text { Income } \\
\text { category } 1 \\
(=100 \%)\end{array}$ & $\begin{array}{l}\text { Income } \\
\text { category } 2 \\
(=150 \%)\end{array}$ & $\begin{array}{l}\text { Income } \\
\text { category } 8 \\
(=250 \%)\end{array}$ \\
\hline Federal Renublic & $\%$ & $\%$ & $\%$ & $\%$ & $\%$ & $\%$ \\
\hline of Germany d & 62.6 & 60.5 & 39.3 & 84.3 & 84.3 & 55.7 \\
\hline France ${ }^{d}$ & 71.9 & 72.3 & 67.6 & 79.6 & 73.7 & 66.4 \\
\hline Great Britain & 59.1 & 56.1 & 63.8 & 81.6 & 67.7 & 64.5 \\
\hline Sweden & 104.1 & 81.5 & 58.2 & 131.6 & 103.8 & 80.2 \\
\hline Switzerland ${ }^{e}$ & 82.6 & 76.0 & 45.6 & 95.6 & 91.7 & 57.6 \\
\hline Belgium ${ }^{d}$ & 46.8 & 42.9 & 39.7 & 60.6 & 58.1 & 56.3 \\
\hline Canada ${ }^{d}$ & 53.1 & 35.5 & 21.3 & 62.1 & 44.5 & 29.2 \\
\hline $\mathbf{U S A}^{d}$ & 60.4 & 47.2 & 29.1 & 71.4 & 59.0 & 38.6 \\
\hline
\end{tabular}

a As a rule, this includes the basic pension of the statutory social security scheme, complementary retirement benefits from additional social insurance and/or company-provided pension schemes as well as welfare benefits. The pension computation is based on three different income categories.

$b$ Gross pension income as percentage of final gross earnings.

$c$ Net pension income as percentage of final net earnings.

d Not including retirement benefits of a company-provided pension scheme (criteria : less than one half of the employees are members of a company-provided pension scheme).

e Assumption : that the company pension scheme currently being debated in parliament is enacted according to the terms of the Bill.

As was mentioned earlier, determining the benefits offered by so-called occupational old-age schemes, mainly company-operated pension funds, presented major problems in the case of most countries. The criterion of including occupational social insurance benefits only if a majority of employees were members of a pension fund has, in particular, led to some classification difficulties. In other countries the criterion of majority membership may be fulfilled, but the benefits of the various pension funds forming the second tier may vary so much that they cannot be meaningfully included in the investigation. When interpreting the comparison it must therefore be taken into consideration that, due to the difficulties encountered, only the benefits of the second tier in Great Britain, Sweden and Switzerland could be incorporated into the statistics.

Furthermore, individual financial provisions for old age within the framework of private capital formation, whose effectiveness depends largely on the amount of income and the effective tax load, were not included in the calculations. In this respect perhaps more than in any other, Switzerland occupies a privileged position, as illustrated by the high rate of private savings capital formation on the part of broad segments of the population. 
Pensions can be index-linked to changes in living costs in two ways : either they are tied to the fluctuations in price levels or they are linked to wage and salary developments (generally only if these levels rise). In times of high inflation rates, the continuous adjustment of pensions, or indexation, assumes great political significance. An example serves to illustrate this point. In the western industrial nations, a pensioner at the age of 65 has an average life expectancy of about 15 years. An assumed average annual inflation rate of $5 \%$ would reduce the purchasing power of a monthly pension amounting to Sfr. 1000 by roughly one half over these 15 years. This means that the pension would have to be doubled over the course of 15 years in order to preserve its purchasing power. On the other hand, if the pension payments are linked to the average annual wage and salary increases and this rate is assumed to be $7 \%$, the pension amount would have to rise to Sfr. 2759 per month after 15 years, almost triple the original sum. Among the countries examined, only the Federal Republic of Germany has formalized the adjustment of pensions to wage and salary increase through legislation. In most of the remaining countries, the pension levels have been linked to changes in consumer prices.

Table 3 - Regular pension age and possibilities of early retirement benefits (as at January 1976)

\begin{tabular}{|c|c|c|c|}
\hline \multirow[t]{2}{*}{ Country } & Men & Women & $\begin{array}{l}\text { Conditions for Early } \\
\text { Retirement Benefits }\end{array}$ \\
\hline & $\begin{array}{l}\text { Regular Early } \\
\text { pension retirement } \\
\text { age at }\end{array}$ & $\begin{array}{l}\text { Regular Early } \\
\text { pension retirement } \\
\text { age at }\end{array}$ & \\
\hline
\end{tabular}

Federal Republic

\begin{tabular}{|c|c|c|c|c|c|}
\hline of Germany & 65 & 63 & 65 & 60 & $\begin{array}{l}\text { No reduction after } 35 \text { years of } \\
\text { covered employment (men) }\end{array}$ \\
\hline France & 60 & - & 60 & - & $\begin{array}{l}\text { Where retirement is postponed } \\
\text { after age } 60 \text {, pensions are in- } \\
\text { creased by } 20 \% \text { for each year } \\
\text { of deferment }\end{array}$ \\
\hline Great Britain & 65 & - & 60 & - & - \\
\hline Sweden & 65 & 60 & 65 & 60 & $\begin{array}{l}\text { The pension is reduced by } 0.5 \% \\
\text { for each month of early re- } \\
\text { tirement }\end{array}$ \\
\hline Switzerland & 65 & - & 62 & - & - \\
\hline Belgium & 65 & 60 & 60 & 55 & $\begin{array}{l}\text { The pension is reduoed by } 5 \% \\
\text { for each year of early retirement }\end{array}$ \\
\hline Canada & 65 & - & 65 & - & - \\
\hline USA & 65 & 62 & 65 & 62 & $\begin{array}{l}\text { Reduction of the accumulated } \\
\text { pension entitlement by } 5 / 9 \% \\
\text { for each month of early re- } \\
\text { tirement }\end{array}$ \\
\hline
\end{tabular}


In most of the countries investigated, men become entitled to the regular retirement pay after the age of 65 but the possibility exists in some nations to retire at an earlier age if one is willing to accept a reduced pension (see Table 3). In the Federal Republic of Germany, the earliest retirement age has been set at 63 years, in the United States at 62 and in Belgium and Sweden as low as 60 years. No such options are open to prospective old-age pensioners in Switzerland, Great Britain and Canada to date. In France the regular pension age is 60 . Where retirement is postponed after age 60 , pensions are increased by 20 percent for each year of deferment.

Social case No. 2 shows the amount of widows' and orphans' pension after decease of the father in a traffic accident - even caused by him - outside his professional activity, in relation to his last gross and net earned incomes.

Table 4-Survivors income a of a family with two children after the husband's death due to an accident (as at January 1976)

\begin{tabular}{|c|c|c|c|c|c|c|}
\hline \multirow[t]{3}{*}{ Country } & \multicolumn{3}{|c|}{ Gross Income Comparison } & \multicolumn{3}{|c|}{ Net Income Comparison } \\
\hline & \multicolumn{3}{|c|}{$\begin{array}{l}\text { Survivors income in } \% \text { of final } \\
\text { earnings before deduction of taxes } \\
\text { and social security contributions } b\end{array}$} & \multicolumn{3}{|c|}{$\begin{array}{l}\text { Survivors income in } \% \text { of final } \\
\text { earnings after deduction of taxes } \\
\text { and social security contributions }\end{array}$} \\
\hline & $\begin{array}{l}\text { Income } \\
\text { category } 1 \\
(=100 \%)\end{array}$ & $\begin{array}{l}\text { Income } \\
\text { category } 2 \\
(=150 \%)\end{array}$ & $\begin{array}{l}\text { Income } \\
\text { category } 3 \\
(=250 \%)\end{array}$ & $\begin{array}{l}\text { Income } \\
\text { category } 1 \\
(=100 \%)\end{array}$ & $\begin{array}{l}\text { Income } \\
\text { category } 2 \\
(=150 \%)\end{array}$ & $\begin{array}{l}\text { Income } \\
\text { category } 3 \\
(=250 \%)\end{array}$ \\
\hline Federal Republic & $\%$ & $\%$ & $\%$ & $\%$ & $\%$ & $\%$ \\
\hline of Germany & 62.8 & 52.7 & 33.8 & 83.6 & 72.7 & 47.7 \\
\hline France & $27.4^{d}$ & $15.4^{d}$ & $39.3 d$ & $\bullet$ & $\bullet$ & $\bullet$ \\
\hline Great Britain & 98.6 & 70.7 & 57.8 & 109.9 & 75.6 & 59.5 \\
\hline Sweden & 89.7 & 71.4 & 51.6 & 121.0 & 106.1 & 91.2 \\
\hline Switzerland e & 95.3 & 96.8 & 92.2 & 107.5 & 113.3 & 108.4 \\
\hline Belgium & 60.3 & 50.2 & 41.3 & 72.2 & 64.5 & 59.7 \\
\hline Canada & 48.5 & 32.9 & 20.0 & 55.7 & 40.6 & 27.1 \\
\hline USA & 97.5 & 77.2 & 47.4 & 111.5 & 94.4 & 62.2 \\
\hline
\end{tabular}

a As a rule, this includes the basic pension of the statutory survivors insurance, the pension of the public accident insurance scheme, if any, supplementary pension benefits of a company-provided survivors insurance and supplementary benefits such as family allowances and housing aid. The pension computation is based on three different income categories.

$b$ Gross survivors income as percentage of final gross earnings.

c Net survivors income as percentage of final net earnings.

d One-off capital payments are due in addition to widow's pension.

e Assumption : that the company pension scheme currently being debated in parliament is enacted according to the terms of the Bill. 
Social case No. 3 compares the social income of a disabled father (100\% disability) with his last gross and net earned incomes. This comparison is based on the assumption that disability is caused by illness in the first instance, and an accident at work in the second. This example is based on income categories 1 and 2 only.

Table 5 - Invalidity income of a family with three children

if the husband is fully disabled (as at January 1976)

\begin{tabular}{|c|c|c|c|c|c|c|c|c|}
\hline \multirow[t]{5}{*}{ Country } & \multicolumn{4}{|c|}{$\begin{array}{l}\text { Invalidity income } a \text { if disability is } \\
\text { due to sickness or disease }\end{array}$} & \multicolumn{4}{|c|}{$\begin{array}{l}\text { Invalidity income } b \text { if disability is } \\
\text { due to accident }\end{array}$} \\
\hline & \multirow{2}{*}{\multicolumn{2}{|c|}{$\begin{array}{l}\text { Gross Income } \\
\text { Comparison } \\
\text { Invalidity income } \\
\text { in \% of final } \\
\text { earnings before } \\
\text { deduction of } \\
\text { taxes and social } \\
\text { security con- } \\
\text { tributions } c\end{array}$}} & \multirow{2}{*}{\multicolumn{2}{|c|}{$\begin{array}{l}\text { Net Income } \\
\text { Comparison } \\
\text { Invalidity income } \\
\text { in \% of final } \\
\text { earnings after } \\
\text { deduction of } \\
\text { taxes and social } \\
\text { security con- } \\
\text { tributions } d\end{array}$}} & \multirow{2}{*}{\multicolumn{2}{|c|}{$\begin{array}{l}\text { Gross Income } \\
\text { Comparison } \\
\text { Invalidity income } \\
\text { in \% of final } \\
\text { earnings before } \\
\text { deduction of } \\
\text { taxes and social } \\
\text { security con- } \\
\text { tributions } c\end{array}$}} & \multirow{2}{*}{\multicolumn{2}{|c|}{$\begin{array}{l}\text { Net Income } \\
\text { Comparison } \\
\text { Invalidity income } \\
\text { in \% of final } \\
\text { earnings after } \\
\text { deduction of } \\
\text { taxes and social } \\
\text { security con- } \\
\text { tributions } d\end{array}$}} \\
\hline & & & & & & & & \\
\hline & $\begin{array}{l}\text { Cate- } \\
\text { gory } 1 \\
(=100 \%)\end{array}$ & $\begin{array}{l}\text { Cate- } \\
\text { gory } 2 \\
(=150 \%)\end{array}$ & $\begin{array}{l}\text { Cate- } \\
\text { gory } 1 \\
(=100 \%)\end{array}$ & $\begin{array}{l}\text { Cate- } \\
\text { gory } 2 \\
(=150 \%)\end{array}$ & $\begin{array}{l}\text { Cate- } \\
\text { gory } 1 \\
(=100 \%)\end{array}$ & $\begin{array}{l}\text { Cate- } \\
\text { gory } 2 \\
(=150 \%)\end{array}$ & $\begin{array}{l}\text { Cate- } \\
\text { gory } 1 \\
(=100 \%)\end{array}$ & $\begin{array}{l}\text { Cate- } \\
\text { gory } 2 \\
(=150 \%)\end{array}$ \\
\hline & $\%$ & $\%$ & $\%$ & $\%$ & $\%$ & $\%$ & $\%$ & $\%$ \\
\hline $\begin{array}{l}\text { Federal Republic } \\
\text { of Germany }\end{array}$ & 74.6 & 64.4 & 97.3 & 87.4 & 103.0 & 96.1 & 134.4 & 130.5 \\
\hline France & 80.6 & 77.3 & 88.5 & 85.7 & 102.4 & 100.1 & 112.4 & 110.7 \\
\hline Great Britain & 92.0 & 57.6 & 114.8 & 73.8 & 133.0 & 85.4 & 165.9 & 109.4 \\
\hline Sweden & 116.1 & 89.7 & 134.9 & 106.4 & 127.4 & 99.3 & 137.0 & 115.6 \\
\hline Switzerland e & 96.5 & 95.3 & 109.8 & 116.5 & 96.5 & 95.4 & 109.8 & 116.5 \\
\hline Belgium & 80.5 & 76.2 & 94.7 & 95.1 & 107.6 & 105.5 & 110.0 & 108.3 \\
\hline Canada & 64.9 & 41.1 & 74.0 & 50.4 & 96.5 & 89.7 & 110.0 & 110.1 \\
\hline USA & 82.8 & 63.4 & 93.3 & 76.7 & 82.8 & 80.0 & 93.3 & 96.8 \\
\hline
\end{tabular}

a As a rule, this includes the basic government disability insurance, supplementary pension payments from company-provided disability insurance and additional benefits, in particular special allowances for children. The pension computation is based on two different income categories.

$b$ As a rule this consists of the basic government disability insurance plus a disability pension from the government accident insurance.

c Gross pension income as a percentage of final gross earnings.

d Net pension income as a percentage of final net earnings.

- Assumption : that the company pension scheme currently being debated in parliament is enacted according to the terms of the Bill.

From a financial viewpoint, the breadwinner's invalidity due to either accident or sickness poses the largest problem for the family. Considerable differences in the benefit 
and compensation levels can be noted in this insurance branch, which depend in turn on the question of whether disablement was caused by accident or by sickness and also if it occurred in the course of employment or not.

Invalidity pensioners are placed in a considerably better financial position if the disability was the result of an employment-related accident or an occupational disease. In most of the countries investigated, the disability pension is then higher than former net earnings for both income categories.

Social case No. 4 shows a comparison of the unemployment income of a family with 3 children with the last earned gross and net incomes.

Table 6 - Unemployment compensation a of a family with three children (as at January 1976)

\begin{tabular}{|c|c|c|c|c|c|c|}
\hline \multirow[t]{4}{*}{ Country } & \multirow{2}{*}{\multicolumn{3}{|c|}{$\begin{array}{l}\text { Gross Income Comparison } \\
\text { Unemployment compensation as a } \\
\text { percentage of final earnings before } \\
\text { deduction of taxes and social } \\
\text { security contributions } b\end{array}$}} & \multicolumn{3}{|c|}{ Net Income Comparison } \\
\hline & & & & \multicolumn{3}{|c|}{$\begin{array}{l}\text { Unemployment compensation as a } \\
\text { percentage of final earnings after } \\
\text { deduction of taxes and social } \\
\text { security contributions } c\end{array}$} \\
\hline & $\begin{array}{l}\text { Income } \\
\text { category } 1 \\
(=100 \%)\end{array}$ & $\begin{array}{l}\text { Income } \\
\text { category } 2 \\
(=150 \%)\end{array}$ & $\begin{array}{l}\text { Income } \\
\text { category } 3 \\
(=250 \%)\end{array}$ & $\begin{array}{l}\text { Income } \\
\text { category } 1 \\
(=100 \%)\end{array}$ & $\begin{array}{l}\text { Income } \\
\text { category } 2 \\
(=150 \%)\end{array}$ & $\begin{array}{l}\text { Income } \\
\text { category } 3 \\
(=250 \%)\end{array}$ \\
\hline & $\%$ & $\%$ & $\%$ & $\%$ & $\%$ & $\%$ \\
\hline $\begin{array}{l}\text { Federal Republic } \\
\text { of Germany }\end{array}$ & 72.5 & 61.2 & 39.9 & 94.5 & 83.1 & 55.8 \\
\hline France & 91.2 & 90.7 & 90.6 & - & • & - \\
\hline Great Britain & 84.4 & 51.3 & 36.6 & 105.2 & 67.6 & 48.1 \\
\hline Sweden & 91.3 & 69.3 & 43.2 & 95.8 & 87.8 & 71.1 \\
\hline Switzerland & 83.2 & 80.0 & 51.1 & 91.6 & 91.8 & 61.6 \\
\hline Belgium & 74.2 & 58.3 & 37.5 & 87.2 & 72.8 & 53.8 \\
\hline Canada & 70.1 & 49.7 & 30.4 & 73.8 & 55.9 & 37.6 \\
\hline USA & 62.6 & 48.3 & 29.0 & 70.5 & 58.5 & 37.7 \\
\hline
\end{tabular}

a As a rule, this includes unemployment cash payments and supplementary benefits such as allowances for children, etc. Computation is based on three different income categories.

$b$ Gross earnings as a percentage of final gross earnings before unemployment.

$c$ Net earnings as a percentage of final net earnings before unemployment.

In most countries surveyed, unemployment payments are today granted for periods varying from 30 to 52 weeks. However, unemployed persons need not fear for their material subsistence even after this period has elapsed because most countries subsequently extend public assistance and supplementary allowances of some sort. It should be pointed out, however, that such welfare benefits are without exception lower than unemployment compensation and that the recipient must, as a rule, submit 
evidence of his or her need. Such worries are unknown to Belgian wage earners who are out of work because the cash benefits of unemployment insurance in that country are paid for an unlimited period.

Social case No. 5 compares the income situation of a family with children, with that of a family without children. Calculations are based on income variant I. The average income of a childless couple is fixed at $100 \%$.

The presentation of data concerning social benefits for families is made more difficult by the fact that the term "family social policy" often lumps together benefit measures as different from one another as : children's allowances; tax relief motivated by social policy considerations; educational allowances; preferential health insurance premium rates; and even housing subsidies. The comparison prepared for the study is limited to the two most important benefit schemes, namely family allowances and tax deductions for dependents. The gross earnings of a family with one, two, three and six children are compared with the income of a couple without children. The amount deducted in the form of income taxes and social insurance contributions allows certain conclusions to be drawn in respect of the tax relief granted. The calculations were based on income category 1 .

Table 7 - Income comparison a of families with 1,2,3 or 6 children with a couple without children (As on January 1976)

\begin{tabular}{|c|c|c|c|c|c|c|c|c|}
\hline \multirow[t]{4}{*}{ Country } & \multicolumn{4}{|c|}{ Gross Income Comparison } & \multicolumn{4}{|c|}{ Net Income Comparison } \\
\hline & \multicolumn{4}{|c|}{$\begin{array}{l}\text { Before deduction of taxes and } \\
\text { social security contributions } b\end{array}$} & \multicolumn{4}{|c|}{$\begin{array}{l}\text { After deduction of taxes and } \\
\text { social security contributions } c\end{array}$} \\
\hline & 1 Child & $\underset{\text { dren }}{2 \text { Chil- }}$ & $\begin{array}{l}3 \text { Chil- } \\
\text { dren }\end{array}$ & $\begin{array}{l}6 \text { Chil- } \\
\text { dren }\end{array}$ & 1 Child & $\begin{array}{l}2 \text { Chil- } \\
\text { dren }\end{array}$ & $\begin{array}{l}3 \text { Chil- } \\
\text { dren }\end{array}$ & $\begin{array}{l}6 \text { Chil- } \\
\text { dren }\end{array}$ \\
\hline & $\%$ & $\%$ & $\%$ & $\%$ & $\%$ & $\%$ & $\%$ & $\%$ \\
\hline $\begin{array}{l}\text { Federal Republic } \\
\text { of Germany }\end{array}$ & 102.9 & 107.0 & 113.9 & 134.8 & 103.9 & 109.5 & 119.0 & 147.4 \\
\hline France & 100.0 & 104.6 & 112.4 & 142.5 & 103.2 & 110.1 & 120.1 & 155.2 \\
\hline Great Britain & 100.0 & 103.0 & 106.0 & 117.9 & 104.4 & 111.2 & 117.3 & 139.7 \\
\hline Sweden & 105.3 & 110.6 & 115.8 & 131.7 & 107.9 & 115.7 & 123.6 & 147.2 \\
\hline Switzerland d & 102.5 & 105.0 & 107.4 & 114.9 & 103.5 & 108.2 & 111.9 & 122.6 \\
\hline Belgium & 106.2 & 116.0 & 129.5 & 171.0 & 111.0 & 125.2 & 144.1 & 208.0 \\
\hline Canada & 102.7 & 105.3 & 108.0 & 116.0 & 103.6 & 107.2 & 110.8 & 121.6 \\
\hline USA & 100.0 & 100.0 & 100.0 & 100.0 & - & - & $\bullet$ & $\bullet$ \\
\hline
\end{tabular}

a Includes child allowances only, not any educational supplements, school money, etc.

$b$ Gross comparison: before taxes and social charges.

c Net comparison : after taxes and social charges. The difference between the gross and net comparisons proves particularly extensive here, as tax legislation in most countries provides additional tax relief for families with many children.

d Child allowances in Switzerland vary from canton to canton. Our comparison is based on the Canton of Zurich. 


\subsection{Financing of social spending as seen by individual working households}

Having ascertained the demand for social services on the part of individual working households in certain social positions in Tables 2 to 7 , the next step is to record and compare the effective burdens on working households in the various countries. It will of course be necessary to consider the tax burden on earned income in addition to national insurance contributions, since the financing structures of the various welfare states do reveal basic differences. This consideration of tax burden is problematic in so far as it is impossible to break down taxes by allocation. Furthermore, social service spending is frequently financed by means of excise duties or special taxes (V.A.T., taxes on tobacco and alcohol, etc.).

The following comparison shows the burden on a gross, earned income of taxes and social charges in the various countries examined. The starting point is once again the average earned income of non agricultural wage earner with two children (income category 1); the rates of burden on income category $2(150 \%$ of 1$)$ and on income category $3(250 \%$ of 1$)$ are also calculated.

Table 8 - Taxes and social security contributions as percentage of family earnings (4 Persons) ${ }^{a}$

\begin{tabular}{|c|c|c|c|c|c|c|c|c|c|}
\hline \multirow[t]{3}{*}{ Country } & \multicolumn{3}{|c|}{$\begin{array}{l}\text { Income Taxes } c \text { as } \\
\text { Percentage of Gross } \\
\text { Earnings } b\end{array}$} & \multicolumn{3}{|c|}{$\begin{array}{l}\text { Social Security Con- } \\
\text { tributions as Per- } \\
\text { centage of Gross } \\
\text { Earnings } b\end{array}$} & \multicolumn{3}{|c|}{$\begin{array}{l}\text { Taxes and Social } \\
\text { Security Contribu- } \\
\text { tions as Percentage } \\
\text { of Gross Earnings }\end{array}$} \\
\hline & $\begin{array}{l}\text { Income } \\
\text { cate- } \\
\text { gory } 1\end{array}$ & $\begin{array}{l}\text { Income } \\
\text { cate- } \\
\text { gory } 2\end{array}$ & $\begin{array}{l}\text { Income } \\
\text { cate- } \\
\text { gory } 3\end{array}$ & $\begin{array}{l}\text { Income } \\
\text { cate- } \\
\text { gory } 1\end{array}$ & $\begin{array}{l}\text { Income } \\
\text { cate- } \\
\text { gory } 2\end{array}$ & $\begin{array}{l}\text { Income } \\
\text { cate- } \\
\text { gory } 3\end{array}$ & $\begin{array}{l}\text { Income } \\
\text { cate- } \\
\text { gory } 1\end{array}$ & $\begin{array}{l}\text { Income } \\
\text { cate- } \\
\text { gory } 2\end{array}$ & $\begin{array}{l}\text { Income } \\
\text { cate- } \\
\text { gory } 3\end{array}$ \\
\hline & $\%$ & $\%$ & $\%$ & $\%$ & $\%$ & $\%$ & $\%$ & $\%$ & $\%$ \\
\hline $\begin{array}{l}\text { Federal Republic } \\
\text { of Germany }\end{array}$ & 9.8 & 12.6 & 19.0 & 15.1 & 14.9 & 10.3 & 24.9 & 29.5 & 29.3 \\
\hline France & 0.7 & 4.3 & 5.9 & 8.7 & 8.6 & 7.9 & 9.4 & 12.9 & 13.8 \\
\hline Great Britain & 16.5 & 18.4 & 21.7 & 5.3 & 4.9 & 3.0 & 21.8 & 23.3 & 24.7 \\
\hline Sweden & 29.7 & 37.9 & 49.4 & - & - & - & 29.7 & 37.9 & 49.4 \\
\hline Switzerland & 3.1 & 6.7 & 13.4 & 11.3 & 14.4 & 10.9 & 14.4 & 21.1 & 24.3 \\
\hline Belgium & 8.4 & 13.9 & 22.6 & 8.1 & 8.3 & 8.1 & 16.5 & 22.2 & 30.7 \\
\hline Canada & 8.3 & 15.9 & 24.3 & 4.7 & 3.2 & 2.0 & 13.0 & 19.2 & 26.3 \\
\hline USA & 6.7 & 12.4 & 19.8 & 5.8 & 5.9 & 3.9 & 12.5 & 18.3 & 23.7 \\
\hline
\end{tabular}

a Computations are based on three different income categories.

$b$ Earnings from employment plus family allowances.

$c$ Includes all direct income taxes payable by the employee.

In any assessment of these rates of income burden, the employee is of course particularly interested in his disposable earned income. We can see here that the countries examined can be roughly divided into two groups. In the Federal Republic of Germany, Sweden and Great Britain, even income variant I has a deduction burden of some $25 \%$. In the other countries, the employees dispose of some $85 \%$ net of their original gross earned income. 
It is not surprising to find that Swedish income are taxed highest. We must remember however that having paid his taxes, the Swedish worker has no more national insurance contributions to pay (with the exception of certain voluntary unemployment insurances). His disposable income can therefore be fully compared with that of his German or British partner.

A comparison of income categories $2(150 \%$ of 1$)$ and $3(250 \%$ of 1$)$ likewise shows quite different rates of burden. With the exception of the Swedish tax rate - in both categories over $100 \%$ above that of the country with the lowest burden - tax and social charges in these income brackets absorb between 20 and 30 per cent of the gross earned income.

As regards the financing of social security, there is in most countries the tendency, sometimes strong, to finance existing and new social expenditure increasingly or exclusively by means of employer contributions. From the point of view of a nation's economy as a whole, the differentiation between employer and employee contributions may be splitting hairs, in as much as social spending is generally recorded as an additional wage component. Nevertheless with an increased financing of social expenditure through employer contributions, the risk exists that the cost-consciousness of the social service "consumer" (especially in the health service or in the case of short-term redundant benefits) will be entirely lost, which in turn may lead to an indirect increase in social spending.

The following table shows that employer contributions to social security financing in many countries already considerably exceed worker contributions, with the Swedish system being particularly in advance on this point.

Table 9 - Employer share of total security contributions ${ }^{a}$

\begin{tabular}{|c|c|c|c|}
\hline Country & $\begin{array}{l}\text { Income } \\
\text { category } 1 \\
(=100 \%)\end{array}$ & $\begin{array}{l}\text { Income } \\
\text { category } 2 \\
(=150 \%)\end{array}$ & $\begin{array}{l}\text { Income } \\
\text { category } 3 \\
(=250 \%)\end{array}$ \\
\hline & $\%$ & $\%$ & $\%$ \\
\hline $\begin{array}{l}\text { Federal Republic } \\
\text { of Germany }\end{array}$ & 52.6 & 52.7 & 53.7 \\
\hline France & 80.8 & 78.5 & 75.6 \\
\hline Great Britain & 60.7 & 60.8 & 60.8 \\
\hline Sweden & 100.0 & 100.0 & 100.0 \\
\hline Switzerland & 49.5 & 46.2 & 48.5 \\
\hline Belgium & 80.2 & 80.5 & 80.7 \\
\hline Canada & 59.0 & 61.3 & 65.3 \\
\hline USA & 59.4 & 58.8 & 58.1 \\
\hline
\end{tabular}

a Employer and employee contributions.

One feature of social security policy is seen in the allocation of responsibility for security measures to society as a whole. In financial terms, this development can be 
demonstrated by a comparison of disposable net earned income with overall social expenditure per employee.

Table 10 - Overall taxes and social charges per employee in comparison with disposable earned income ${ }^{a}$

\begin{tabular}{|c|c|c|c|}
\hline \multirow[b]{2}{*}{ Country } & \multicolumn{3}{|c|}{$\begin{array}{l}\text { A disposable net earned income of } 100 \text { units is compared with } \\
\text { the following tax and social expenditure: }\end{array}$} \\
\hline & $\begin{array}{l}\text { Income } \\
\text { category } 1 \\
(=100 \%)\end{array}$ & $\begin{array}{l}\text { Income } \\
\text { category } 2 \\
(=150 \%)\end{array}$ & $\begin{array}{l}\text { Income } \\
\text { category } 3 \\
(=250 \%)\end{array}$ \\
\hline Federal Republic & $\%$ & $\%$ & $\%$ \\
\hline of Germany & 53.2 & 58.5 & 55.8 \\
\hline France $^{b}$ & 61.9 & 55.1 & 51.2 \\
\hline Great Britain & 38.4 & 40.3 & 38.8 \\
\hline Sweden & 71.6 & 96.9 & 144.4 \\
\hline Switzerland & 29.7 & 42.3 & 45.8 \\
\hline Belgium & 98.0 & 72.3 & 93.3 \\
\hline Canada $^{c}$ & 27.1 & 30.6 & 40.6 \\
\hline USA & 23.3 & 32.6 & 38.1 \\
\hline
\end{tabular}

a The disposable earned income of a working household with two children (=s gross earned income + child benefit less taxes + social charges) is compared with overall social charges (employer + employee contributions) and with the tax burden on the employee's income.

$b$ Earned income without child benefit.

c Assumption : contribution to sickness insurance $=$ employer + employee $50 \%$ each.

\subsection{Social security in the industrial society : reality or illusion?}

The results of the present benefit and cost comparison permit us to draw some interesting conclusions as to the establishment and expansion trends of social security policy in the industrial nations of the West. The salient result of our socio-political appraisal is that the financial assistance offered by the social services generally extends far beyond the poverty line.

Before completing our assessment of results, it should be explained that the collection of figures and statistics was complicated by a number of factors. Owing to the often extremely complicated pensions formulae (conversion of last earned income to the so-called pension-forming income) and tax legislations (calculation of the taxable income), available information, though uniform at the start, had to be supplemented on several occasions. In addition to this, private or company supplementary services are available to a large extent in a variety of countries without there being any data available on them. This study encompasses only company social services when, in a given country, at least 50 per cent of all employees possess a claim to those services 
averages are available. On the basis of these criteria, only the company social benefits and the state or the employer contributes to their financing and/or where representative in Great Britain, Sweden and Switzerland could be taken fully into account.

Despite these limitations and obstacles, this comparison makes a valuable contribution to socio-political orientation, which an overall consideration reveals the following focal points :

1. The level of social security benefits and services in the countries in question is today surprisingly high. In the most important branches of social insurance, the objectives of social security policy - guarantee of subsistence plus safeguarding social status - have been largely fulfilled. And in no fewer instances, the disposable social income exceeds the last disposable earned income.

2. Within the group of countries examined, there are considerable differences in the benefits level of the insurance sectors examined. The widespread generalization that the "traditional " welfare states (in this case Sweden, Federal Republic of Germany and Great Britain) possess a tangibly higher level of social services cannot be upheld as such. Thus we find, in all social instances in the various countries, services which in no way fall short of the service level of the "established" welfare states.

3. Study of the countries examined as a representative selection of Western industrial nations reveals that the average level of compensation for the various national insurance sectors in this group of countries is approximately as follows:

\begin{tabular}{lccc} 
& \multicolumn{3}{c}{ Income Categories } \\
& 1 & 2 & 3 \\
& $\%$ & $\%$ & $\%$ \\
Old-age pensions & $70-85$ & $65-80$ & $45-60$ \\
Surviving dependents' pensions & $90-110$ & $75-95$ & $50-70$ \\
Disability pensions & & & \\
- through illness & $95-110$ & $80-100$ & \\
- through accident & $110-130$ & $110-130$ & $40-60$ \\
Daily unemployment benefit & $75-95$ & $60-85$ &
\end{tabular}

4. The gross level of benefits considered for the lower income group are upvalued by an average 20 per cent. In individual countries with a relatively high tax and social charges burden on earned incomes, the indirect increase in social benefits triggered by tax rates can be as much as $\mathbf{5 0}$ per cent. Apparently these effects of tax policy on the level of social benefits is not regarded as acceptable, otherwise it would be almost impossible to explain the surprising number of service rates of over $100 \%$.

5. Social incomes of over 100 per cent of the last earned income plus astonishingly big differences between the service appropriations within one and the same country indicate the uncoordinated growth in social security systems and show, at the same time, that a high quality of security should be attained with the existing, comprehensive social budget. 
6. A comparison of the burdens on individual working incomes shows a similar picture to that of social service benefits, which is hardly surprising : Swedish rates are the highest in all three income classes. Direct comparison of the benefit level with social-charge rates demands very careful interpretation. It should be remembered that it is impossible to divide the tax burden into separate expenditure items; thus all state expenditure is included indirectly in the comparison. The partially surprising differences between benefits and financing data can be attributed to other reasons still : social spending today is chiefly financed by means of the so-called allocation procedure, which means that the amount of social spending is determined not just by the level of services but also by the relationship of employed persons to social service "consumers", hence by the demographic circumstances of the individual countries. Such a comparison, moreover, does not reveal how frequently the various social services are used, and particularly tangible differences exist in unemployment insurance (e.g. unemployment rate in Switzerland approx. $0.2 \%$; in the U.S.A. approx. $7 \%$ ), in sickness and accident insurance as well as in the demand for social services in general (e.g. more borderline areas in countries with major conurbations, many immigrants, population inflow, etc.).

All these factors make the available data unsuitable for any cost-effect considerations regarding individual systems of social security. Cost-effect analyses and statements on the efficiency of state social security systems require a more comprehensive and detailed approach.

7. As a rough point of departure, we can state that the various income brackets in industrial nations of the West must expect the following average rates of burden (taxes and social charges as percentages of gross earned income)

$\begin{array}{cc}\text { Burden } & \text { Disposable } \\ \text { Rate of } & \text { Income } \\ \% & \%\end{array}$

$\begin{array}{lll}\text { Income category } 1 & 15-25 & 75-85 \\ \text { Income category } 2 & 20-30 & 70-80 \\ \text { Income category } 3 & 20-30 & 70-80\end{array}$

8. The increase in the burden rate from income category 1 to income category 3 $(=250 \%$ of category 1$)$ is surprisingly small. If we remember that the demand for social benefits (as a percentage of earned income) of income category 2 for instance is hardly any lower, and that these income brackets apparently demand more from other state services as well (universities, cultural spending, health service, etc.), we would suspect that the effects of redistribution in the welfare states are not as great as is often supposed.

9. The effective costs of a welfare state are best shown in a recording and comparison of employee and employer contributions and of the tax burden (cf. Table 10, p. 20). This index indicates the risks and limits of the welfare state : burden rates of over $100 \%$ of disposable income are signs of advancing incapacitation of the 
citizen; a reduction in individual responsibility and in the will to self-help in all sectors of society is scarcely avoidable with a policy of this kind.

10. The often impressive range of social services offered should not conceal the fact that the modern affluent society itself has created new social problems at many levels, even though they may appear in a different form and in different social groups. It is hard to forget, for example, that despite billions being spent on pension insurance today, more and more old people feel lonely and isolated. New fringe and problem groups with genuine social needs and concerns are always coming into existence despite increasing social expenditure. Despite an expensive and abundant social bureaucracy, there is no doubt that many of the problems of the truly weak and needy have not yet been satisfactorily solved, even in a welfare state.

There are many reasons for this. First of all, the extensive social bureaucracies are tending towards an increasing legal complication and economization of the social services. The results of this policy are a tangible deficit in the social services sector plus a more rigid and largely cause-orientated compensation system. In addition to this, the right to social services with today's system is in most instances very directly linked with the earned income received up to the time when the claim is made: by his work achievement, the individual can improve and safeguard not just his current but also his future social status. This concept favours the successful, those active in business and industry who dispose of a regular income. But what of those persons with a very low or especially irregular income and who generally continue to depend upon social services (assistance) but who are still close to the minimum subsistence level. In other words and more generally: the modern welfare state finds it difficult to cater for those sectors of society who for a variety of reasons are unable to match up to our society's standards of achievement.

Any change in this policy would of course have far-reaching repercussions in the existing structures of the Western social and welfare states. As long as such a step has to be seen as unlikely for political and economic reasons, the slogan "poverty in an affluent society and welfare state" will continue to have impact.

\section{Basic trends}

\subsection{General}

This section sets out to discuss certain medium- and long-term development trends within the social sector. At the forefront of this discussion is an analysis of potential aspects of social security policies in economically advanced industrial states.

The industrial community of the West is marked by a striving for economic efficiency and social justice. The Welfare State is one answer to this conflict of aims. Looked at from this angle, almost all changes in the economic, political or social structures of a society are part of a causal chain, to be interpreted as socio-political factors of determination and development. Restricting ourselves to a few central factors of influence, we arrive at the following model : 
Fig. 2 - Factors determining social security policy

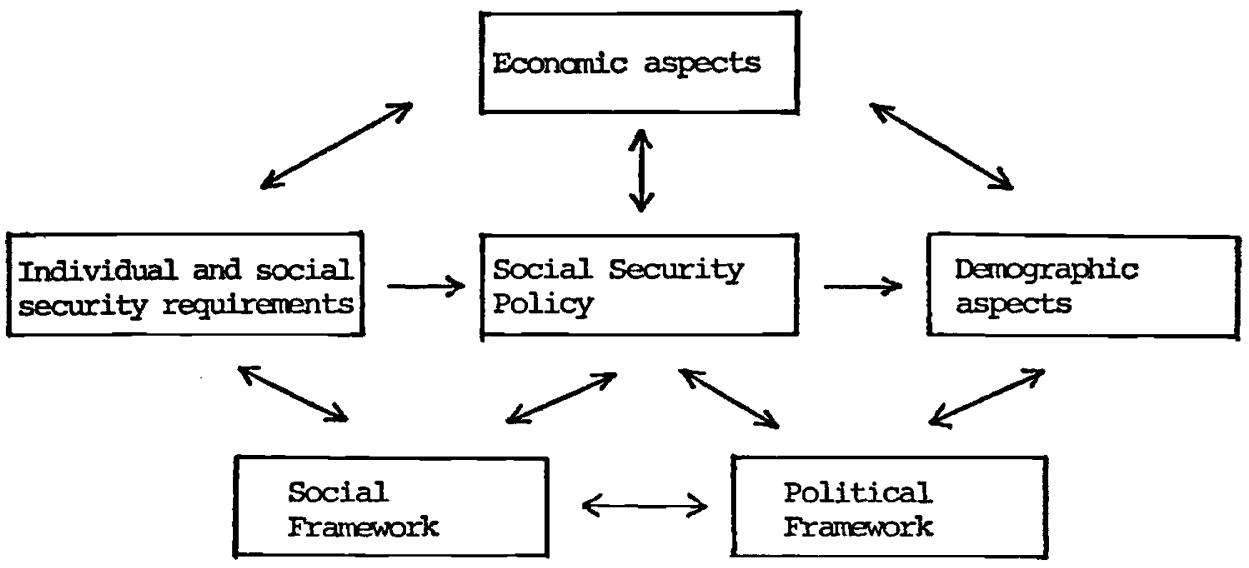

Economic aspects influence both the demand for and - through the available financial margins - the supply of social services. Owing to current major shifts in the age groupings of the population in most industrial states, demographic aspects are pointing to a significant change and increase in the demand for social services. The attitudes of the political decision-makers and the reforming capacity of the corresponding bodies are of paramount importance with regard to future socio-political decisions. Future social conditions represent a mirror image of the future economic and social circumstances within the industrial society. The welfare states of the West are not the outcome of decisions taken arbitrarily, and this fact leads us to ask: What do people really want in the future? Modern requirements research has as its aim the analysis of individual and social security requirements.

When evaluating this model, we should bear in mind that the inter-relationships of the various determining factors are extremely complex; thus, each isolated problem analysis may be classified as arbitrary. In addition, the attempt to discuss the development of such complex systems as those of social security from a chiefly non-national standpoint would seem a somewhat reckless undertaking, especially in view of the plethora of social and economic conditions within the various countries looked at. Nevertheless, there are several reasons which make this attempt appear reasonable.

- This survey encompasses countries (Sweden, Federal Republic of Germany), which already have a decidedly comprehensive supply of social services and which thus enjoy a model character with regard to social developments as seen from other countries; and this aspect should not be underestimated.

- The questions discussed in this study relate chiefly to a few principal problem areas which are not only decisive for the development of social security policies in advanced national economies as a whole, but which also give rise to bitter disputes in all welfare or social states.

- Ever since the last war, we have discerned certain basic trends in the development of social security systems which appear in comparable forms in all the social 
states of the West (general applicability and improved efficiency of social protection, the establishment of supplemental systems, etc.).

Many common features of development along the path from the industrial to the service society as well as increasing alignment tendencies on the level of social policy as on other levels, would lead us to conclude that the future development of social measures will be characterised by comparable trends. Looked at from this angle then, it is hardly surprising that the social states of the West are now confronted with similar conflict situations and causes of disturbance.

\subsection{Establishment and aims of the empirical survey}

The scenario in Section 3.3 on future focal points in the development of social security has been based on a selection of the following methodical approach. First, major points of interest in the survey countries were discussed in interviews with a variety of personalities close to the arena of social policy. With the aid of a questionnaire, we were able to collect additional information on important development tendencies in social security policy. While interview discussions dealt with a relatively limited number of selected problems particularly familiar to the interviewees, the written questionnaire covered the most important problem areas in 21 mainly "inclusive" questions (i.e. a selection of possible answers was given).

A better understanding of the method employed will be obtained from a study of the two examples given below, which are, in fact, two problem areas in which the possibility of far-reaching structural changes within social security were posited.

\section{Example $A$}

Question:

For some time now there has been discussion of whether the present partvoluntary, part-compulsory system of social security (at least as regards personal risk) should be replaced or supplemented by a comprehensive, uniform, and compulsory system of compensation. Approaches to comprehensive compensation systems with the guarantee of a minimum income (negative income tax) or an automatic compensation claim in case of need (on a no-fault basis) have already been made.

By when do you think existing social-security systems might have been replaced by such comprehensive compensation systems (compensation claim in case of need with a large number of new occasions or risks)?

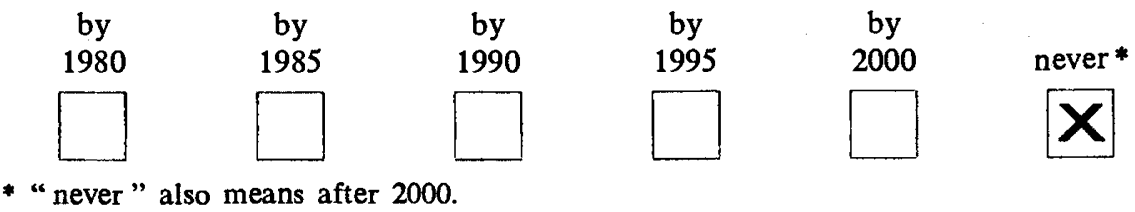

Discussions on these problems, both in a comparison of the answers given by the individual countries as well as within the different political groupings, led to unequivocal results : 
The model of the negative income tax, with regard to future trends in social measures in all countries, is not regarded as an alternative to the existing system of social security. It remains possible, however, that a model of negative income tax for the purpose of the income security of individual population groups (e.g. farmers or families with many children) could be applied, first because attempts in this direction have already been made in most countries, and second because the traditionally highly causal national insurance systems cater for "poverty without visible grounds" either inadequately or not at all.

The various justifications can be reduced basically to five arguments :

1. Plans for a fundamental reorganisation of social security policy are nothing new; such demands have been made at regular intervals in the past (and will probably be in future too). However, the structures of national insurance codes have proved to be extremely stable over the past decades, and, as a rule, major reforms have been carried through under exceptional circumstances only (far-reaching and rapid change in economic and social conditions, world war, etc.).

2. Likelihood of any comprehensive reorganisation recedes as the existing order is increasingly developed. The relative stability of today's order is due mainly to the uniform satisfaction of the security requirements of a multitude of social groups. Because of restricted financial means, the various sectors of the population have to defend their rights to social services in competition with others demanding the same social services. Any improvement in the security of individual strata of society will lead to increased demands by the other sectors, thus every socio-political improvement creates new injustice. This "principle of permanent change in short steps" reinforced by a certain natural dynamism of the various bureaucracies (social security organisations) guarantees the stability of present-day order and leads to increased consolidation of the existing structures for both the supplier of social services and their recipient.

3. The existing plurality within the political decision-making bodies has an additional stabilizing effect and prevents any far-reaching change. The political resources available for the solution of socio-political problems and the existing ability of political bodies to overcome such problems are chiefly absorbed in the solution of isolated material problems of temporarily high priority (e.g. youth unemployment, health services, etc.) and in overcoming financial difficulties respectively.

4. Financial considerations forbid experiments in the existing social order and make such social utopias seem unrealistic.

5. The debate on negative income tax is still largely restricted to an academic dispute. Thus the majority of interviewees, while familiar with the concept in the abstract, had only the vaguest ideas of the possibilities of such a system.

\section{Example $B$}

Question :

Various economic and political indicators suggest that in the years to come there will be relatively fewer funds available for the maintenance and extension of social-security performance goals. As a consequence of this development our society will have to decide on its priorities in the field of social security. 
Which task do you regard as particularly important for the future? What will be done where (i.e. in which field) as a matter of priority in future? (Please indicate which you think are the five most important tasks with the figures 1 to 5 .)

\begin{tabular}{|c|c|c|c|c|}
\hline WHERE WHAT & $\begin{array}{l}\text { Maintenance and } \\
\text { improvement of } \\
\text { financial per- } \\
\text { formance goals }\end{array}$ & $\begin{array}{l}\text { Maintenance and } \\
\text { improvement of } \\
\text { the supply of } \\
\text { social services }\end{array}$ & $\begin{array}{l}\text { Extension } \\
\text { of the group } \\
\text { protected }\end{array}$ & $\begin{array}{l}\text { Other tasks (please } \\
\text { state which) }\end{array}$ \\
\hline Old people's welfare & $\mathrm{X}$ & $\mathrm{X}$ & & \\
\hline Dependents welfare & $\mathrm{X}$ & & & \\
\hline Disability welfare & $X$ & $X$ & & \\
\hline \multicolumn{5}{|l|}{ Sickness benefit } \\
\hline \multicolumn{5}{|l|}{ Accident benefit } \\
\hline Unemployment benefit & $X$ & & & \\
\hline Family allowances & $X$ & $x$ & & \\
\hline $\begin{array}{l}\text { Other areas } \\
\text { (please state which) }\end{array}$ & & & & \\
\hline
\end{tabular}

In the debate on future priorities in social security policy, it was hardly surprising to find that national problems and views were in the forefront of discussion.

An analysis of the various opinions gave the following results :

First, the social security codes of the various countries do not contain identical gaps for isolated risks and/or population groups (e.g. widows' pensions or old-age pensions for women who have not worked for many years, period and amount of daily sickness benefit, inadequate daily unemployment benefit, etc.). The majority of efforts aimed at overcoming this basically known and recognised accumulated demand are given top priority.

Second, discussions on this question largely confirmed a hypothesis on Question 1 that the stability of the social security code is based on multiple dissention among. competing-demand groups - in as much as nearly all imaginable socio-political possibilities were identified at least once as the most vital task for the future.

The different justifications lead to the following trends :

- The realisation seems to be growing in all countries that financial and non-monetary needs of families with many children are to be recognised more and more as a "social risk".

- In the sphere of financial services, there is growing need for improved coordination of the existing supply of services - as a means of saving; and there is growing realisation of this need. Since the coordination of services is often linked with a certain reduction in services, the chances of success of such efforts are put somewhat slight.

- An improvement in the supply of services is to be expected primarily in the field of disability welfare and provisions for old age. 
- The extension of social protection to the entire population continues to be a socio-political requirement, though of relatively lower priority.

- With regard to the alternatives of "improving the supply of social services" or "improving the financial aims of the services", we note that while the former is mentioned more frequently, the financial improvement of individual social services is almost always mentioned as having short-term priority. We can deduce from this that a rapid and meaningful improvement in the supply of social services broadly corresponds to political wishful thinking. While there is general agreement on a solution to the development deficit in the realm of social services being necessary and meaningful, it would seem that this area will be set aside in the future in favour of the politically more effective expansion in financial services. In other words : there is little likelihood of a speedy improvement in the range of services within the scope of social security policy.

- Finally, it is an important factor (and surely no coincidence) that attempts at e.g. the improvement of sociological research or greater emphasis on preventive medicine, etc. were hardly mentioned as being important tasks for the future. Here again we can see that future debate on socio-political development will probably take place within the arena of accepted structures and traditional provinces of the social order.

Overall, we have collected the opinions of some 15 to 25 personalities per country, who were allocated to one of the following groups by reason of their professional or political activity :

- labour representative ;

- management representative ;

- scientist, politician ;

- representative of national insurance administration ;

- representative of private insurance.

The selection of interviewees was made with the aim of collecting the views of important groups directly participating in the socio-political decision-making process.

Finally, an attempt will be made to classify the various opinions and to summarize the most important basic tendencies in social security policy for the period 1990 to 2000. Before we do this however, it is appropriate to recall the relative value of these statements as well as certain key survey experiences.

We feel that the following remarks are important for an understanding of the results of this survey :

- The results are the outcome of some 100 interviews and surveys among leading personalities in 5 European states who, on the basis of their professional activities and knowledge of the subject, are in frequent intensive contact with socio-political problems.

- In all five countries, emphasis was placed on concentrating the debate as far as possible on principal problems and trends in the development of the social state.

- Concrete ideas on the medium and long-term consequences and possibilities of socio-political development are of prime importance for two reasons. First, individual 
social security programmes have to be long-term by the very nature of their aims; and second, the rapid social change in our society favours far-reaching shifts in requirements within the sphere of socio-political objectives. From this aspect, our survey revealed some surprising factors: only a minority of the interviewees is apparently accustomed to looking at and considering the problems consciously, comprehensively and over a long timescale.

Thus the quality of the individual interviews and surveys is shown to have considerable fluctuations from our own viewpoint. This is, however, only a partial disadvantage for the premise selected here, for we must recall that socio-political development has always been shaped more according to pragmatic, day-to-day considerations of policy than on factual, scientific perception.

- Results of this type of survey naturally require very careful interpretation. Thus the relatively small number of answers per question, for example, does not permit us to weight the results by means of frequency distribution. Neither were the interviewees able, for obvious reasons, to dissociate themselves in many instances from a particular commitment to a definite, and for them meaningful, policy. In addition, there is a risk that the answers will be all too influenced by current debate and that development tendencies in quite different directions may be overlooked.

What should not be overlooked however is the conspicuous accumulation of forecasts of important socio-political changes or initiatives for the period 1990 to 2000 , a tendency which can be explained by the fact that many changes within the next 5 to 15 years, i.e. within the foreseeable future, are considered unrealistic. However, as many of the persons questioned regarded the envisaged socio-political changes as meaningful, there is a great temptation to situate desirable but rather unlikely developments in the last few years of the time period in question. For this reason the results require especially careful and critical appraisal.

The foregoing limitations must be borne in mind when the existing results are assessed, and it is therefore necessary to "filter" and appraise the obtained results carefully.

In spite of these reservations, this study demonstrates :

- How personalities of different political leanings in five economically advanced industrial states and societies assess essential questions of social security policy. We may assume here that the problems discussed may be put to debate in this or a similar form in all developed social states within the coming years.

- In this way, we are able to discern aspects which, understood as a possible margin for future development tendencies, can be said to be meaningful and realistic.

\subsection{Basic tendencies in social security policy : a scenario}

In the pages that follow, the opinions of the interviewees on certain questions of principle in the development of social security policies will be set forth. The results given contain an assessment of the questionnaires as well as an appraisal of those interviews which are more important in numbers and significance. 
1. Provided political plurality is retained, the structures of social security systems are hardly likely to change over the coming years. Suggestions for replacing the complex and difficult social security regulations by a new and comprehensive compensation system (e.g. no-fault system, negative income tax, etc.) continue to be the basis of academic discussion only.

2. The process whereby social security policy develops in the coming years will coincide to a large extent with past experience: socio-political aims and programmes will continue to be dictated first and foremost by the multitude of shortterm needs of day-to-day policy and by the wholly vested and established interests of individual political groupings.

Equipping socio-political programmes for long-term aims and projects is possible to a very limited degree only, despite the recognised necessity for this. Likewise, the influence of sociological research on future developments in the welfare state will be slight.

3. Adherence to existing structures however should not be equated with a refusal to expand the instruments of the welfare state. The democracy of competition, a certain natural dynamism of the existing bureaucracies together with the impossibility of ever attaining socio-political objectives all create the cause and driving forces for future demands for an expansion of welfare measures.

In this light, a substantial reduction in existing social services seems scarcely feasible, and great-to-paramout importance will be attributed to the social sector in the future. Thus any necessary reduction in public spending will perforce affect other sectors first (armed forces, transport, education).

4. The existing aim of social security policy - (financial) security of existence for the whole population at all social strata - still holds good, and tendencies in this respect are towards a rise in the mandatory insurance threshold, while demands for compulsory insurance within the traditional national insurance sectors remain a highly debatable matter.

5. However, within the scope of an overall socio-political development trend, the demand for a continued extension of social security policy is diminishing in importance. Following the efforts made over the past few years, chiefly with a view to securing an income at all levels of society, future socio-political debates will take place mainly in those spheres which are of prime significance for the quality of life of the individual and family.

Important initiatives and changes are thus to be expected in the field of working conditions (with popular and current key words such as: co-determination, humanizing of working life, etc.) and of family policies (living conditions, the double workload of working mothers, etc.).

This is first due to the fact that essential objectives of this policy have already been achieved for a major part of the population, and second that possible financial squeezes in national programmes may well lead to intensified socio-political demands and activities in those sectors which are not the cause of any direct tangible social expenditure.

6. Parallel to his tendency, most of the interviewees expect to see a return to the potential of individual (private) and especially corporate initiatives. 
Increased social spending always gives rise to bitter struggles for distribution because of diminishing growth prospects. Reforms in the field of a nationally organised social security policy will lead in future to even lengthier disputes. By contrast, reforms and improvements in corporate social services are frequently based on collective bargaining agreements which in turn can lead to a compromise much more rapidly (e.g. reduction of social dissent to two items : less time spent on lengthy examination procedures, improved and more flexible appraisal of the financial potential).

The establishment of supplementary pension systems on a collective bargaining basis in Sweden (for upper-echelon income earners) or the increasing application of a multi-stage system to cover long-term redundancy in countries which previously opposed such ideas, are signs of this kind of policy. The corporate social policy (in all senses) must be expected to gain rapidly in significance.

7. The following tendencies are to be expected within the individual sectors of social security :

- The various national social security codes reveal considerable differences as regards existing gaps in social services offered (e.g. insufficient sickness benefit rules in Switzerland, unsatisfactory widows' pensions in the Federal Republic of Germany, incomplete unemployment insurance in Sweden, inadequate disability pensions in Great Britain, etc.). Short-term priorities and expansion programmes vary accordingly. The interviewees however expect that the major gaps in national social security systems will be filled relatively soon, i.e. within the next five to ten years.

- In the field of social security there is a marked tendency to improve services within the various sectors to bring them to a comparable level. Here, service guidelines for an average working household of $75-80 \%$ of the last available net income for long-term unemployment and $80.90 \%$ in the case of sickness, accident or redundancy seem to represent $a$ kind of threshold.

In the case of long-term disability, trends towards extending the benefit systems should gather impetus.

The increasing implementation of a model for a 2 or 3 tier ald-age, dependents' and disablement welfare system is first the result of the financial strains of the state pension scheme and second serves mainly to safeguard acknowledged services for the middle-to-high income brackets.

- The coming years should see the creation and expansion of the possibility of a flexible retirement age in all countries. A general reduction of the pensionable age is unlikely, but nevertheless feasible if conditions on the labour market continue to deteriorate.

- Problem area No. 1 is sickness insurance and the health service. The alarming financial outlook for the health sector must mean far-reaching changes. Political decisions at the very highest level cannot now be avoided, and tangible intervention and restrictions by the health service are seen as inevitable.

8. Lack of progress in social service developments is gradually being remedied, but continues to exist fundamentally. The lack of financial resources and political initiatives prevent the satisfactory expansion of welfare measures. 
9. Social security systems will in future demand a greater share of the GNP. Even in the absence of comprehensive development projects, it is probable that these social outgoings will have grown by a net $30-50 \%$ by the year 2000 . The dominating cost factors are the unhappy prospects in sickness insurance, unfavourable demographic conditions and deteriorating growth in the economy.

10. It is possible to lay down distinct limits for social security policies : the scope and limits of welfare expenditure will be determined largely by economic policy potential and public opinion. It must be assumed that an increasing proportion of the population will accept the socio-political aims of the welfare state.

\section{Aspects of social security : consequences for private insurance}

There can be no doubt that the development of the social state has a direct and manifold influence on trends in private insurance. A potential displacement of private insurance, i.e. the loss of markets, is in the forefront here, and this applies to life assurance as well as to sickness and accident insurance. However, direct effects must also be anticipated on product development, sales channels and of course on premium policy.

The consequences of socio-political developments on private insurance was discussed in all the survey countries, both in the written questionnaires and during personal interviews. The following examples will clarify this premise.

Question:

Our last question concerns the future development of personal insurance as you see it.

It can be assumed that the extension of social security will directly affect primarily personal life assurance and health and accident insurance. How do you see things developing here?

The effect of the future development of social security on

- will be nil

— will be slight

- will be considerable : substantially fewer people will require supplementary personal-insurance coverage

- will be considerable : substantially more people will want supplementary personal-insurance coverage Argument :

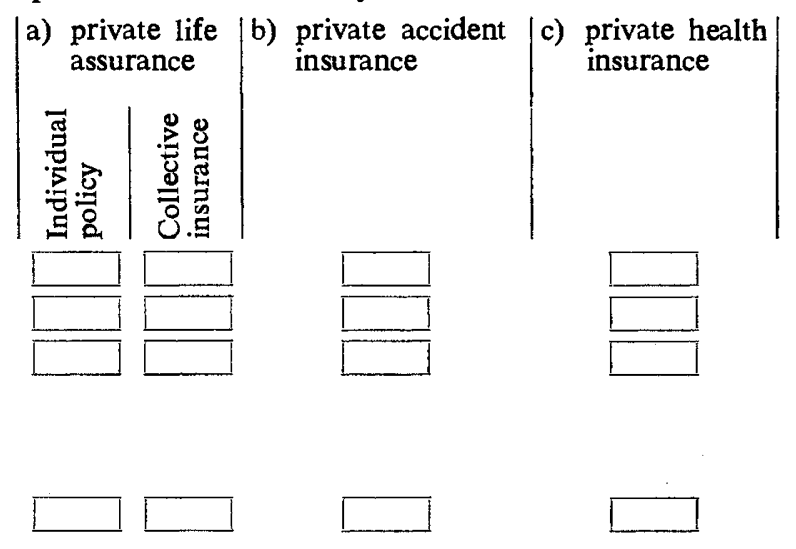




\section{Question :}

The future position of personal insurance will of course be influenced by other factors besides the development of social security. The following list contains a number of developmental factors that we consider will to a greater or lesser degree determine the future market opportunities of personal insurance.

Which 3 factors in each branch of insurance do you see as being most important ? (Please indicate them with the numbers 1 to 3 .)

\section{Extension of social security}

Increase in per capita income

Development of the inflation rate

Extension of tax-supported insurance saving

Inadequacy of or dissatisfaction with state social-security coverage

Demographic changes (birth rate, life expectancy)

Scientific progress (medicine, gerontology, etc.)

Changes in the political power structure

Other factors

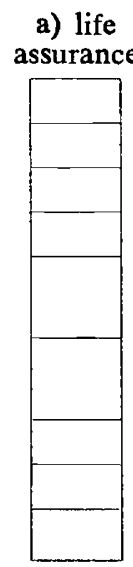

b) health insurance

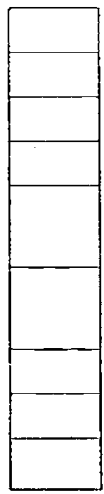

c) accident insurance

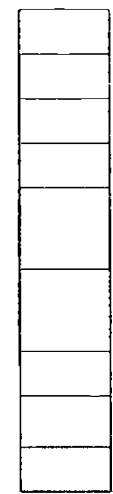

Discussion :

The focal points of opinion can be summarized as follows :

1. The prospects for private insurance are, indeed, very directly influenced by sociopolitical activity, though not exclusively. The majority of experts believe, for example, that the consequences of economic aspects and financial considerations (inflation, increasing affluence, tax policy, etc.) are of greater significance especially for the life assurance sector.

2. The repeated optimism as regards the growth potential of private insurance is based, above all, on the following arguments :

- a glance at developments over the past years shows that, despite rapid inroads made by national insurance, private insurance can be said to be a growth sector. The growth rate in premium volume (life and non-life) in the ten years from 1964 to 1974 was between 4 and $6.8 \%^{1}$ in advanced industrial societies.

Likewise, the average growth rates in individual and group life assurance portfolios from 1950 to 1971 (i.e. during the heyday of social security expansion)

1 Source : SIGMA, "The most important insurance countries of the world in 1974 ", p. $5 \mathrm{ff}$. 
considerably exceeded the average annual growth of gross national product in most countries 2 :

$\begin{array}{lccc}\text { France } & \begin{array}{c}\text { Average } \\ \text { Growth } \\ \text { GNP }\end{array} & \begin{array}{c}\text { Average } \\ \text { Growth } \\ \text { Ind. Ins. }\end{array} & \begin{array}{c}\text { Average } \\ \text { Growth } \\ \text { Group Life } \\ \text { Assurance }\end{array} \\ \text { Federal Republic of Germany } & 10.0 & 14.9 & 23.5 \\ \text { Sweden } & 9.4 & 14.3 & 14.0 \\ \text { Switzerland } & 9.0 & 3.9 & 28.4 \\ \text { Great Britain } & 8.5 & 8.1 & 18.5 \\ & 7.0 & 10.3 & 13.0\end{array}$

Likewise a comparison of capital insurance portfolios as a percentage of national income in 1972 proves that, in spite of high inflation rates, private life assurance continued to be an attractive savings alternative ${ }^{3}$ :

$\begin{array}{cc}\text { Capital Insurance Portfolios } \\ \text { Compared with National Income } \\ 1967 & 1972 \\ 144 & 140 \\ 83 & 103 \\ 67 & 74 \\ 32 & 55 \\ 37 & 44\end{array}$

The capital insurance portfolio figures for Sweden are particularly surprising here. These figures show that private affluence is just as important for the taking out of life assurance as for instance the state of development of national insurance schemes.

- Other growth potentials in life assurance will of course depend to a large degree on future trends in national tax legislations. Within the three-tier model of old-age welfare (Tier 1: national insurance to cover minimum subsistence; Tier 2: occupational benefit schemes; Tier 3: private insurance), in most countries, Tiers 1 and 2 enjoy substantial tax benefits, but Tier 3 (private life assurance) is far less favoured.

It must be assumed that, owing to the tightness of public budgets, harldy any improvements in the tax treatment of life assurance will be achieved within the coming years. There are even tendencies in certain countries towards reducing benefits which have already been granted (e.g. Sweden).

- The demographic aspects, despite population stagnation or even absolute population decline (as is currently the case in the Federal Republic of Germany, Sweden, Great Britain and Switzerland), will nevertheless ensure an increase

2 Source : von Wartburg, W., Insurance in Switzerland, 1975, Berne, p. $115 \mathrm{ff}$.

3 Source: Life Insurance Fact Book, 1974. 
in potential customers in the coming years. If we assume that people begin to think about their health seriously as from the age of 30 , and take an interest in their old-age welfare from the age of 40 to 50 , the coming years should see an appreciable expansion in the market for sickness and life insurance.

- From the economic aspect too, there is rather an increase in the demand for private insurance protection. Growth in individual affluence increases the funds available for personal provision, and continued economic uncertainty increases the savings rate of private households. This increased tendency to save - which has been clearly experienced over the last 2 years in the Federal Republic of Germany, Great Britain and even Switzerland - is reflected in the number of new policies, notwithstanding all secondary economic conditions.

- The analysis of the aspects of social security policy shows that future sociopolitical activities should lie less in the area of national insurance systems than has been the case in past years. Parallel to this trend, we can discern signs that additional service improvements in social security (especially safeguarding of an attained social status for the higher income brackets) will be increasingly realised by means of (collectively bargained) additional or supplemental systems. Both these tendencies should have positive long-term effects on the continued expansion of private welfare measures whether on an individual basis or with the aid of private insurance companies.

- Forecasts in the sphere of sickness and accident insurance are subject to factors of greater uncertainty as a result of the high contingency of problems in the health sector. Private insurance has so far succeeded in establishing and maintaining a market for supplemental insurance cover on a private basis despite partly nationalised health services, and the ability of private insurance to react quickly and more flexibly to changes in demand requirements (retentions, comprehensive preventive services, etc.) can be seen in this light as a significant advantage for the future.

3. Possible danger to private insurance of a market displacement would seem on the decline for the time being. However, the increasing inclusion of individual insurance in a comprehensive socio-political welfare concept could well reinforce the tendency to encroach tangibly upon the scope of activity of private insurance (additional regulations on premium planning, investment and reserve policy, etc.).

\section{Social risk policy in the family and household}

Having reviewed future social-security policy trends and the repercussions of sociopolitical developments on individual insurance, it is now necessary to outline several fundamental considerations concerning future social security policy organisation, from a family and household point of view 4 .

4 Detailed considerations on this theme have already been published by Haller M. : "Soziale Risikopolitik in Familie und Haushalt", in Schweizerische Zeitschrift für Volkswirtschaft und Statistik, Heft 3/1976 s. 329 ff. ; Ackermann W. : "Social Risk Management : A Way out of the Crisis of the Welfare State?", in Foresight, The Journal of Risk Management, Volume III, No. 3, London 1977, p. 2 ff. 
Fundamental rethinking of current extensive social security measures seems essential in view of the ongoing unpleasant economic and unfavourable demographic perspectives. Over the coming years, and in view of the concurrent, complex social and political circumstances, welfare societies should be forced to establish priorities in order to obtain the best in security from a limited security budget.

The "social risk policy" concept can be viewed as a combination of elements of "risk policy" and "social policy". The socio-political component has to decide on the form in which society is to guarantee the required security. Here it is particularly important that comparative values be determined for the principles of solidarity, subsidiarity and self-responsibility. It is the task of the risk policy component to ensure that security requirements are met in as comprehensive and efficient a manner as possible (cf. fig. 3 , below).

The systematic recording, evaluation and economic control of risks is the basis of risk policy - or, in a more restricted sense - of risk management. The social security system has the task of identifying as comprehensively and efficiently as possible, evaluating and controlling (especially from the economic point of view) several risk situations for individuals and their families which are of considerable social and socio-economic significance (loss of earnings due to old age, death, invalidity, unemployment, etc.). Consequently, the prime objective is, as far as possible, to prevent these risks occurring and, should they nevertheless arise, to minimize their repercussions.

Fig. 3 - Social risk policy : combination of security and equation

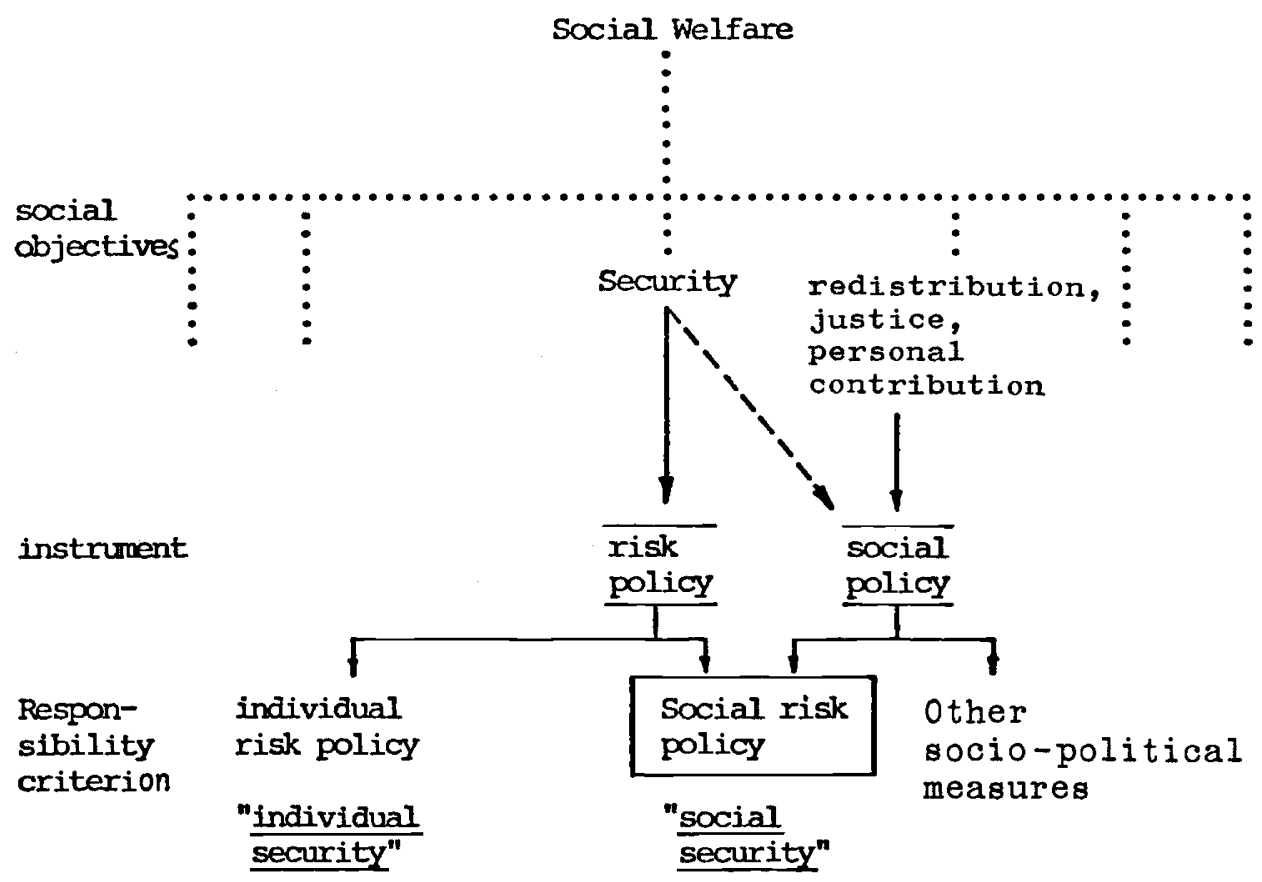


This transfer of the evaluation of the security and risk problems of individuals and families thereby leads to the following catalogue of requirements.

- First of all there is the identification of the risk-threatened system. This depends on the characteristics of the case, since the risk action is frequently transmitted to other, only indirectly related, systems. A case of disablement, for example, has not only its own human tragic aspect but also the financial problems that it entails both for the disabled person and his dependents. Consequently, it is essential to co-ordinate the social security measures, especially for closely related and dependent groups.

- The family's security requirements are the outcome of family risks. These risks usually entail pronounced financial consequences. In addition there is also the property aspect, the impairment of human and material property and facilities, just as in the case of familiar risks of decisive significance. Here again, the relevant conclusions must be drawn: security measures must be (more) deliberately coordinated bearing in mind the property aspect of the risk.

- As far as the level of priority of security measures is concerned, it is good policy to classify risks into high, medium and low risk on the basis of risk severity.

From the risk severity viewpoint, the risk can also be viewed as a column bearing on each family. Initially, the burden needs not be divided perpendicularly into individual components (old age, sickness, accidents, etc.). With regard to security, the column could be divided horizontally into black, grey and white zones being respectively those of high, medium and low risk. The corresponding class transitions are easy and depend on individual circumstances.

In the case of a limited security budget - and this applies to both the individual and the social security measures - prime attention must be devoted to the high or "catastrophe" risks (cf. fig. 4, p. 38).

- In considering familiar risks, a certain part of the risk should deliberately be left to the family. Risk participation and the resultant increased risk awareness, leads to greater risk avoidance and risk reduction and heightened safety consciousness.

- In individual areas of social insurance, duration of the benefit is a decisive factor in the assessment of security measures. For example, a reduction in sickness benefit after several weeks of sickness - relatively common internationally - amounts to an infringement of the catastrophe principle.

- A sensible risk conception provides security measures for all essential disturbance causes. This principle requires full-circle cover, maximum uniformity in protection against loss of earnings and supplementary expenses in accordance with the catastrophe principle.

- Whereas all countries provide cover for the traditional disturbance causes - old age, death, invalidity, sickness, accidents and unemployment - there are great differences in the way it is decided which social groups are in distress and should receive social security benefits. Traditionally benefits were granted to disadvantaged population sections. For historic reasons, there is a tendency to maintain this concept and aim it at employees or specific groups of employees. 
Fig. 4 - Social security provisions on the full-circle principle

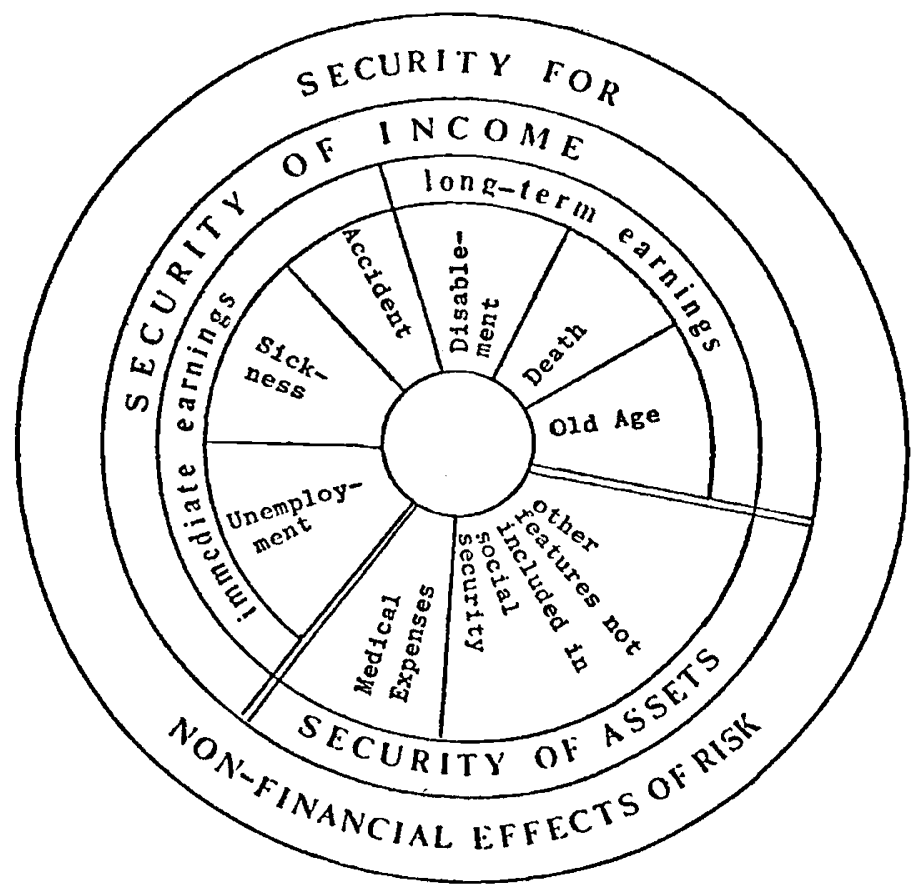

Need for protection based on a contractual relation between employer and employee, no longer appears practical today, although the needs of the employee's household are of prime significance in this context. From the risk policy point of view, anybody exposed to severe risks and who does not take the necessary precautions (either through lack of awareness or the appropriate means) is in jeopardy. To base this situation on an employer-employee relationship or assign benefits merely at random to particular social groups, seems incorrect in view of the current rapidity of economic and social change.

A comprehensive risk policy will therefore provide basic protection, within the framework of the social security benefits, for the whole population or the whole workingpopulation. Insurance density is therefore a further important qualitative characteristic for the evaluation of social security programmes.

An optimal risk policy concept is shown graphically in fig. 5 (p. 39).

Clearly the benefits provided by the numerous independent areas of social security must be seen as an entity, as far as the family-at-risk is concerned. Should benefits be missing in a given area of the social security system then overall security is compromised.

Similar conclusions are valid in the assessment of benefit levels. Knowledge of risk policy leads to demand for benefit levels which are as uniform as possible. However, to disregard this demand would diminish the quality of the whole programme. Naturally, 
the level of benefit is open to discussion. This question must be seen and determined against a background of higher socio-political objectives. In any case one should face two basic requirements : on the one hand the protection against catastrophic risks and on the other hand, the preservation of personal and direct risk control responsability.

Fig. 5 - The "Security Cube" of social security

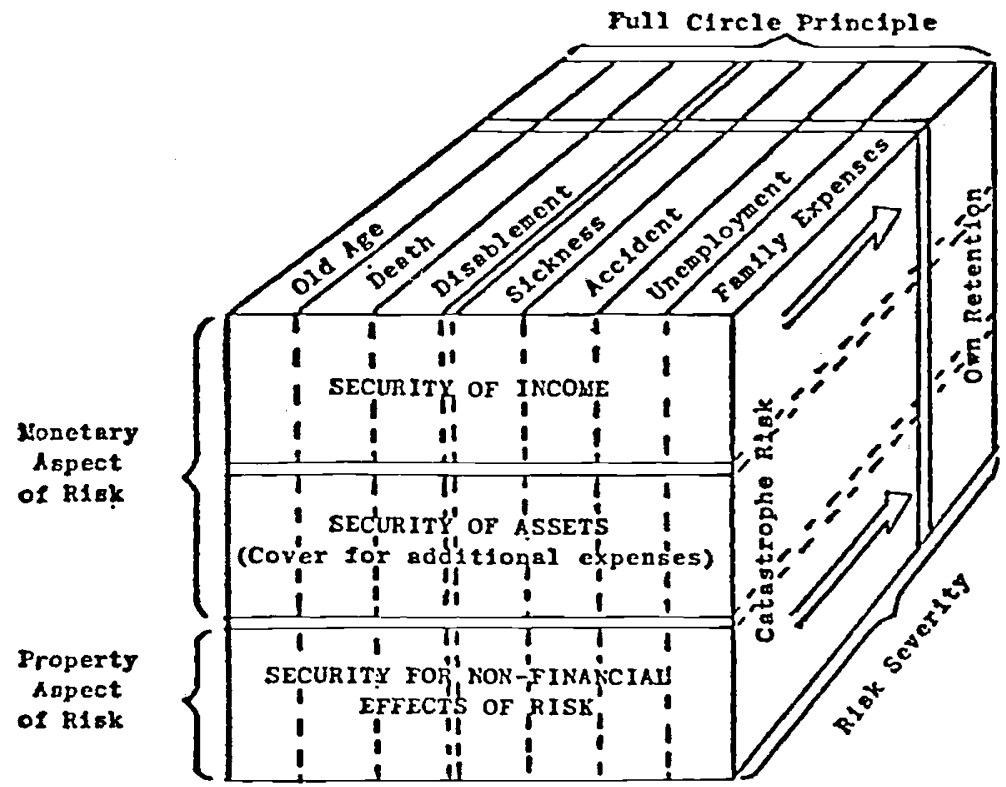

To summarize, the following factors should be noted:

1. The family as a risk unit;

2. Consideration of the property and monetary aspects of the risk ;

3. Structuration of the security measures according to the principle of risk severity, i.e. :

- consideration of the catastrophe principle,

- self-participation in risk to influence the behaviour of the risk-threatened system,

- unrestricted benefit claims, within a given time frame;

4. Extensive benefit claims according to the full circle principle;

5. Basic protection for the whole population (insurance density).

To what extent is this catalogue of requirements met within the framework of the national social security regulations?

- The analysis of social security policy in this survey indicates repeated disregard for the above-outlined requirements in practically all national social security systems.

- Whereas, in the majority of cases, the principle of the family as a risk unit will hardly be impaired by determining financial-benefit objectives as a percentage of the previous earned income, this would not be the case should the remaining requirements and principles of the risk policy often be neglected! 
- In nearly all countries, there is a pronounced imbalance between the financial benefit claims and the measures for dealing with the property aspect of the risk. Whereas pension and daily allowance level is in many cases satisfactory, most welfare states are distinctly lacking in the scope of the social service benefits.

- Infringement of the risk severity principle is especially evident in many systems. In many cases, the monetary benefit is still only 20 to 30 per cent of former income, whereas for other causes (on the basis of identical situations), the benefit may even exceed 100 per cent of the last earned income. For example, loss of employment due to invalidity is often dealt with a particularly unbalanced way; whereas for sickness invalidity, compensation may be less than 60 per cent of last earned income, occupational-accident invalidity pensions may considerably exceed former net earned income. There are historical reasons for this. However, the family in question can scarcely be expected to show much appreciation for historical factors.

- Optimal application of the full circle principle, often suffers from strongly fluctuating insurance density as well as from the unbalanced compensation levels.

These few indications already imply that the social security systems by no means merit good marks from the risk policy viewpoint. Yet, the cost-saving argument is not so much in the foreground here (benefit rates of over 100 per cent must be considered as a socio-political luxury) as the reproach of an insufficient level of security. Better organisation of a complex, badly administered system and a sensible distribution of existing resources could improve social conditions as a whole and also the effectiveness of the social state.

The development of an optimal system cannot be achieved merely by risk policy considerations. Within the socio-political framework, there is doubtless room for different political views. The involvement of political beliefs, however, does not mean that technical considerations could at present have any more validity. On the contrary, they provide a basis for combining the various risk groups with both essential sociopolitical principles - subsidiarity and solidarity.

In social security, the solidarity principle is met to first and includes concern for equality, justice and also mutual aid concepts. Solidarity can be at 3 levels from the monetary point of view :

- The first level of solidarity involves the insurance institution as such which provides the risk-threatened system with benefits which would not otherwise be available.

- The second level of solidarity is the direct responsibility of society for the family's risk policy. Many people feel "insecure" but are incapable of expressing their need for protection; consequently, society acts through legislation to determine urgent security needs and provides assistance for those in distress. This pressure to selfhelp is via compulsory insurance.

- Since not all families have the material and spiritual wherewithal for adequate self-help, external help is provided by society either by personal help or joint payments. Joint payments come within the scope of social insurance as a deliberate deviation from the individual equivalence principle and by not demanding contributions from all those insured, which would be necessary in the case of pure risk solidarity. The contribution is paid by the other insured persons or from national 
finances. This income re-distribution is usually encountered in state or semi-state organisations.

The three levels of solidarity form a pyramid, on the base of risk solidarity which is found in both individual and social security. Here tax privileges for the relevant institutes may come into play. Higher up the pyramid, we have compulsory insurance and, finally - as an example of the strongest financial solidarity - income re-distribution (Fig. 6).

Fig. 6 - Solidarity pyramid (example of social insurance)

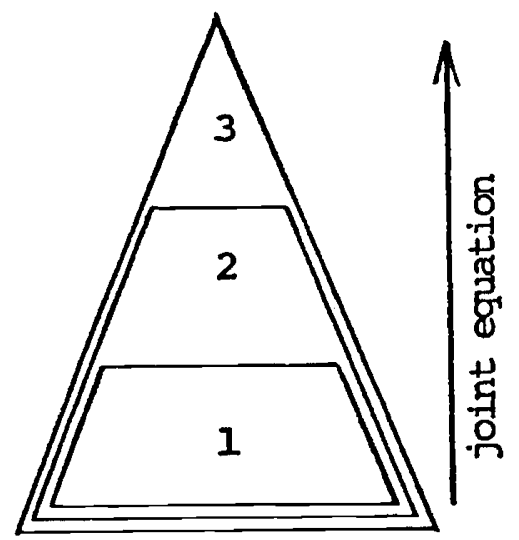

3 Outside help personal help and possibly income re-distribution

$2 \frac{\text { Pressure to self-help }}{\text { obligation to security }}$

1 Help to self-help encouragement of the risk solidarity

When should these different levels of solidarity be applied? The answer emerges from the inter-relation between the risk and the social policy elements. The normal family cannot support alone the high risks (complete invalidity, long hospital stays, no income in old age, etc.) and consequently has to protect itself. Since they may not appreciate the high risk or fail to understand the lack of security, legal pressure is necessary. Since, compulsory security may exceed reasonable expenses, outside direct or financial help may appear advisable. In view of the severity of the risk, social responsibility is essential and solidarity is justified.

The subsidiarity principle supplements the solidarity principle. Society uses it for the pursuit of other objectives, in particular individual freedom and responsibility for self-help. This principle also affirms social equality and that the aid should be supplementary in that help will be provided when the individuals own means are exhausted - the individual or the family should first meet, from their own resources, whatever is possible. In this way, those at risk thus bear the first responsibility. Should the task overburden them, then the help of others will be called on : first, the next largest group, in particular the employer, then that of society and, in particular, the state. Situating help on a scale of urgency also forms an integral part of the subsidiarity principle : subsidiarity is "solidarity where necessary".

This hierarchy of security requirements has shown that low risks should not be transferred since self-help tends to increase risk awareness and safety consciousness, and stimulates the individual's efforts to ensure his own security. Therefore, subsidiarity also means controlling security - related behaviour. The demand for the individual 
to assume responsibility for low risks is also justified, since the individual and the family unit can, in fact, bear the consequences of the risk actually occurring. This statement defines the limits of the self-responsibility : self-responsibility ends when the outcome of the risk leads to an unreasonable burden on the family and household. It also ends when the risk is intentionally or unintentionally transferred to others.

This relationship between risk policy and social policy can be seen clearly from Fig. 7 which presents the social objectives which, on the basis of criteria for security responsibility, lead to differences between individual and social security. The matrix columns show the structure of familiar risks as a function of risk severity. In this way, conditions for the effective security are met :

Fig. 7 - Relationship between risk policy and social policy

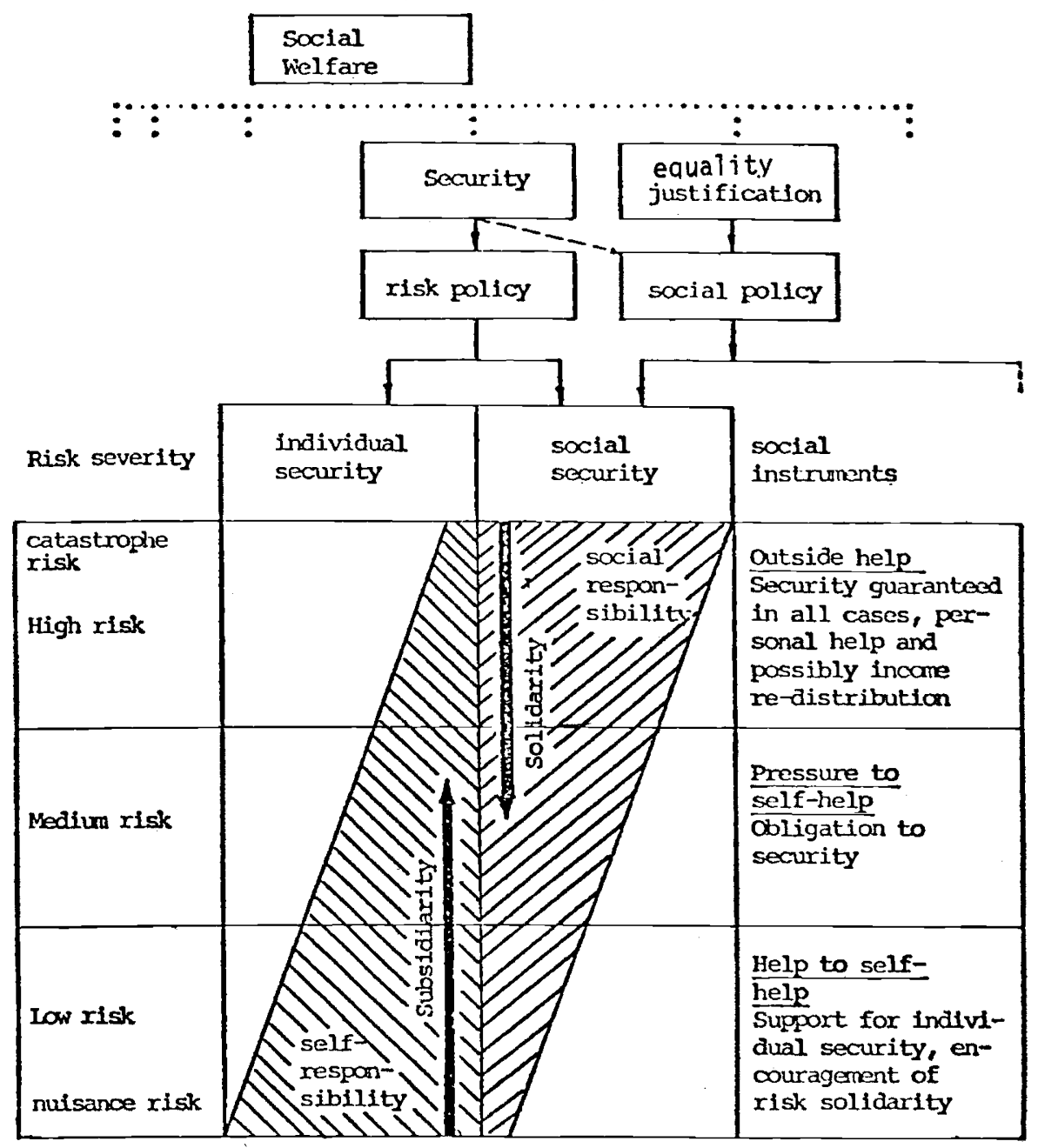


The dimensions of what - in its entirety might embody optimal security of the members of society - are shown graphically in two areas corresponding to individual and social security responsibility. Both principles of social organization have their origin in contrasting cases of risk severity: solidarity in the case of catastrophic risk, subsidiarity for minor risks within the family. If there is constant movement from one extreme case to the other, then the reciprocal significance of these principles is lost. No situation can be classed as solely self-responsibility or social responsibility; each wheighed solution of the social risk problem contains both elements. The main weight of individual security lies in the low and medium risk zones. In the area of medium risks, the importance of the gradually self-responsibility decreases as we move towards social responsibility. With regard to low risks, social encouragement of individual precautions (pressure and outside help for those in distress) will be matched to increasing risk severity. The greater the strain placed on society in assuring security of the family, the more it will be necessary to restrict it to essentials, i.e. to the highrisk area.

Are such considerations attainable in practice? In view of the long history of social security institutions and the way in which social security has for historical reasons been squandered on a multitude of special laws and insurance institutes, it would be illusory to propose a fundamental re-orientation, all the more so since the results of the survey (see section 3.2) indicate the impossibility of a radical new structuring of collective security measures. Much, however, would be achieved if more attention were devoted to social-risk policy demands when carrying out various socio-political reforms or implementing new socio-political programmes. 